\title{
Inhalation challenges with agents causing occupational asthma
}

\author{
O. Vandenplas*, J-L. Malo**
}

\begin{abstract}
Inhalation challenges with agents causing occupational asthma. O. Vandenplas, J-L. Malo. CERS Journals Ltd 1997.

ABSTRACT: Occupational asthma (OA) is steadily emerging as the principal cause of respiratory disease due to the workplace environment. One of the key means to ascertain diagnosis of $\mathrm{OA}$ is specific inhalation challenge (SIC) with occupational agents. This review: 1) describes the methodology of SIC, with a special emphasis on procedures aimed at increasing the safety and validity of these tests; and 2) outlines the roles of SIC in the diagnosis of $\mathrm{OA}$ in clinical and medicolegal assessment, epidemiological studies, surveillance programmes and the investigation of the pathophysiological mechanisms of asthma and OA. We discuss areas of future development, including the development of apparatus which allows exposure of subjects to low and stable concentrations of the occupational agent and the assessment of preventive procedures.

Eur Respir J 1997; 10: 2612-2629.
\end{abstract}

*Dept of Chest Medicine, Mont-Godinne Hospital, Catholic University of Louvain, Yvoir, and Fonds des Maladies Professionnelles, Brussels, Belgium. **Dept of Chest Medicine, Sacré-Coeur Hospital, Montréal, Canada.

Correspondence: 0. Vandenplas, Dept of Chest Medicine, Mont-Godinne Hospital, 5530-Yvoir, Belgium

Keywords: Asthma, bronchial provocation test, occupational disease

Received: January 201996

Accepted after revision June 161997

Work carried out at Sacré-Coeur Hospital is supported by the Centre québécois d'excellence en santé respiratoire (Fonds de la recherche en santé du Québec - Glaxo Wellcome), the Medical Research Council of Canada, the Institut de recherche en santé et sécurité du travail du Québec and the Commission de la santé et sécurité du travail du Québec.
The purpose of specific inhalation challenge (SIC) is to assess airway responsiveness to "sensitizing" substances as opposed to nonspecific stimuli such as pharmacological agents (i.e. histamine, methacholine), cold air and exercise. The major rationale for performing SICs is to document organ-specific responsiveness rather than local nonspecific responsiveness or immunological sensitization to the agent.

SICs with common sensitizers such as pollens were introduced as early as 1873 by Charles Blackley [1] and was often used by various investigators in the 20th century $[2,3]$. Based on the work of Colldahl [4], PePys and co-workers [5-7] described dual reactions in the case of other immunologically mediated bronchoalveolar reactions such as allergic bronchopulmonary aspergillosis [5], farmers' lung [6] and bird fancier's lung [7]. In 1970 Pepys suggested the use of specific inhalation tests in the investigation of occupational asthma as follows (J-L. Malo, Personal communication):

"The next development was in occupational asthma. We did not know how to test by aerosol inhalation with agents such as toluene diisocyanate (TDI), etc. or with potentially irritant or extremely potent allergens such as the platinum salts.

The answer to this was the patient with severe asthma clearly related to his work. He made the boats for the Oxford and Cambridge boat race and used a two part polyurethane/TDI marine varnish. As soon as I heard this, he was asked to provide these two separate materials which are mixed together prior to use. The first day, he painted on a slab of wood with the polyurethane with no effect, whereas the mixture tested in the same way the next day elicited asthmatic reactions. This was the answer to the problem and the origin of simulated "occupational type" provocation tests, in other words a piece, and usually a very, very small piece of real life as a highly analytical, precise and reproducible form of testing. There can be no objections to this if carried out properly since it is no different from the work exposure".

Originally, SICs were carried out in the corridors of the Brompton hospital with people walking about. A well-ventilated cubicle in a room was later made available. A series of reports was published in Clinical Allergy beginning in 1972, dealing with dusts, powders, fumes, gaseous emanations and aerosols [8, 9]. For these tests, subjects were asked to reproduce their normal work in a small cubicle under close supervision and with functional assessment. A summary of the proposals for the tests was later published [10] and SIC proved to be an invaluable tool for identifying a wide variety of agents causing occupational asthma (OA) [11]. Summary guidelines for performing SICs with occupational agents have been proposed within wider scope documents issued by the American Academy of Allergy and Clinical Immunology [12] and the European Respiratory Society [13].

In the original description of the test [10], SIC was regarded as an empirical approach in which a worker is 
asked to reproduce his working environment. Although this approach is still the case in some instances, recent developments in the methodology of these tests prompt a different description of SIC as an experimental testing, in which the respiratory effect of an agent present in the workplace is assessed ideally under controlled conditions, including the generation of low and stable concentrations of this agent. Indeed, according to the definition of OA [14], the agent should be able to induce a bronchial response at low concentrations that are unlikely to act through a nonspecific irritant mechanism.

\section{Methodology}

\section{Exposure to occupational agents}

Safety requirements. Since SIC can cause asthmatic reactions, the safety requirements for these tests should be stringent. They should be carried out only in specialized centres by trained personnel under the close supervision of physicians who have expertise in this field. A standardized protocol of exposure to the occupational agent and patient monitoring should be strictly followed. Equipment for the emergency treatment of acute asthmatic reactions should be readily available. Indeed, the real threat of these tests still lies in the difficulty in predicting the extent of the immediate reaction with its onset, which can be extremely rapid. This being said, there are means to control the magnitude of the immediate reaction. One needs to take into account the clinical history, baseline airway calibre, level of nonspecific bronchial hyperresponsiveness, and degree of immediate skin reactivity to the occupational agent in the case of a water-soluble product causing responsiveness through an immunoglobulin (Ig)E-mediated mechanism. The late reaction is much easier to manage as it takes more time to happen and leaves sufficient time to initiate appropriate treatment. The patient should be monitored in the laboratory for at least $7-8 \mathrm{~h}$ after the end of exposure to detect late asthmatic reactions (LARs). SIC can be performed on an out-patient basis provided that, at the end of the monitoring period, the asthmatic response, when one has been elicited, has adequately improved (forced expiratory volume in one second (FEV1) $>90 \%$ of baseline value), either spontaneously or through the use of an inhaled bronchodilator. The patient should receive precise instructions on how relapsing bronchoconstriction monitored at home with portable instruments assessing peak expiratory flow (PEF) and/or FEV1 should be managed after leaving the laboratory. If a treatment with inhaled $\beta_{2}$-adrenergic agonist does not bring the FEV1 to at least $90 \%$ of baseline value, or if its effect lasts for $<1 \mathrm{~h}$, the patient should be kept in hospital for further observation and adequate treatment

SICs should be performed only in subjects with reasonably stable asthma. Baseline FEV1 should be $>60-70 \%$ of predicted value and/or $>2 \mathrm{~L}[12,13]$. It is also important to ensure that spontaneous fluctuations of FEV1 are $\leq 10 \%$ on a control day. There are contra-indications, such as recent ( $<3$ months) myocardial infarction or cerebral vascular accident, uncontrolled arterial hypertension or heart disease, and pregnancy. Epilepsy requiring drug treatment should be regarded as a relative contraindication [13].
Medications. Oral and inhaled bronchodilators $\beta_{2^{-}}$ adrenergic agents, ipratropium bromide, and slow-release theophylline, as well as antihistamines, cromoglycate, and nedocromil should be withheld according to their duration of action [12, 13]. Ideally, anti-inflammatory medications should be withdrawn before the challenge. However, in subjects with moderate to severe asthma, it may be necessary to continue inhaled or even oral steroids to prevent spontaneous fluctuations of FEV1. In such cases, the total daily dose of steroids should be given in the evening of each day (at least $10 \mathrm{~h}$ before the next test) to maintain asthma stability throughout SIC. Steroids may affect early asthmatic response (EAR) and LAR (see section on pharmacomodulation of asthmatic reactions). However, it has never been demonstrated that steroids completely abolish asthmatic responses to high molecular weight (HMW) and low molecular weight (LMW) agents, although it is likely that the duration of exposure required to induce an asthmatic reaction is longer under steroid treatment. Similarly, it has been shown that steroid treatment does not reduce the diagnostic sensitivity of PEF records at work [15].

Control test. It is essential to perform a control test before the subjects are challenged with the suspected occupational agent. The aim of this control test is to ensure that fluctuations of FEV 1 are $\leq 10 \%$, either spontaneously or, preferably, after exposure to a control substance. This makes it possible to increase the safety of SIC by limiting the test to subjects with reasonably stable asthma. Furthermore, the control test is crucial for a correct interpretation of SIC, as it makes it possible to verify that the reaction to an agent is not due to a nonspecific irritant effect, particularly in subjects with unstable asthma.

The control substance is selected according to the nature of the occupational agent suspected of causing OA: lactose powder for SIC with agent in powder form (i.e. flour, drugs, persulphates, etc.), pine dust for SIC with wood dusts, vinyl gloves for SIC with latex gloves, diluent or polyol component of polyurethane products for SIC with isocyanates, etc.

Delivery procedures. Exposure to occupational agents can be produced in various ways, depending on the physical state of the agent suspected of causing OA. Water-soluble HMW agents can be diluted in saline and administered through a nebulizer according to protocols recommended for ubiquitous inhalant allergens [13]. These protocols take into account the degree of nonspecific bronchial hyperresponsiveness (NSBHR) and immediate skin reactivity to set the starting dose as initially proposed by TIFFENEAU [16] and later confirmed by СоскРОтT et al. [17]. The major limitation is that standardized preparations with known allergen content are not available for occupational agents. Also, some allergens from HMW agents may not be watersoluble [18]. Agents in powder form that are not watersoluble (e.g., wood dusts, antibiotics, persulphate salts, etc.) can be generated as a dry aerosol, either with an apparatus which allows aerosolization of steady and nonirritant concentrations [19-21] or by being tipped 
from one tray to another as initially proposed by PEPYS et al. [10], although it might be awkward, with the latter methodology, to monitor the concentrations of the agent in order to prevent the exposure of subjects to irritant concentrations. Exposure to airborne natural rubber latex can be achieved by handling latex gloves [22].

Isocyanates, a class of agent that frequently causes OA [23], are either generated using one of the methods with closed-circuit apparatus (see below) or in cubicles, as recently reviewed by BANKS et al. [24]: 1) vapours (gas) of toluene diisocyanate (TDI) are obtained by passing a flow of air at ambient temperature onto pure TDI; 2) for hexamethylene diisocyanate (HDI), the commercial product used at work (usually paint hardeners containing various prepolymers of HDI) is nebulized; and 3) for diphenylmethane diisocyanate (MDI), the commercial preparation is heated to about $80^{\circ} \mathrm{C}$. SICs with other agents are currently performed by mimicking the workplace exposure as closely as possible. Several reports indicate that bronchial reactions are affected by the chemical and/or physical properties of the agent [25-27]. SIC should, therefore, be performed by using occupational agents in the same chemical and physical state (i.e., vapour, aerosol, dust, fumes, temperature) as encountered at work.

SICs are usually carried out in an enclosed space (usually 5-8 $\mathrm{m}^{3}$ ) in order to avoid inadvertent exposure of either sensitized subjects or technicians. Such challenge rooms should be equipped with: 1) an exhaust ventilation system, to prevent escape of the tested substances into the laboratory; 2) fans, to ensure adequate mixing of the air in the rooms; 3) large windows that make it possible to have a direct view of the subject during the challenge; and 4) sources of compressed air that can be used whenever aerosolization of solutions is required. The generation and exhaust ventilation processes should be controlled through regulators located outside the challenge rooms.

Level of exposure. The concentrations of occupational agents generated during SIC should be measured according to recommended methods and kept below the threshold limit values (TLV) for short-term exposure. Isocyanate concentrations, for instance, should be continuously monitored using tape monitors with direct readings of the results, and kept below the TLV of 20 parts per billion ( $\mathrm{ppb}$ ) by regulating the generation and ventilation processes. However, for most occupational agents, the concentrations leading to nonspecific irritant effects on the airways remain largely uncertain and require to be more precisely determined.

The concentrations of the agents generated during SIC in challenge rooms are highly variable and may at times be higher than the recommended TLV. This may result in unduly severe asthmatic responses or in nonspecific irritant reactions. Recently developed closedcircuit exposure devices (fig. 1) make it possible to generate steady concentrations of occupational agents in powder form [19-21], of isocyanate vapours [28] or aerosols, and of other vapours (formaldehyde, glutaraldehyde) [29]. These closed-circuit devices provide better control of the intensity of exposure, and may therefore lead to a more accurate investigation of dose- response relationships as well as a more satisfactory standardization of SIC.

Duration of exposure. It is essential that the duration of exposure be increased progressively to prevent the occurrence of unduly severe asthmatic reactions. FEV1 should be assessed immediately after each exposure. If FEV1 falls by more than $10 \%$, it should be reassessed 10 min later, before re-exposing the subject to the occupational agent. The protocol should start with shorter periods of exposure (1 breath, 10s, $30 \mathrm{~s}$ ) and should be more progressive when there is any indication that the subject has a marked NSBHR (provocative concentration of histamine or methacholine causing FEV1 to fall $20 \%$ from baseline (PC20,hist or $\mathrm{PC} 20$,meth, respectively) $<0.25 \mathrm{mg} \cdot \mathrm{mL}^{-1}$ ) or a history of acute severe reactions at work. For agents causing OA through an IgE-mediated mechanism, complete exposure can be performed progressively on one day. The duration of exposure to LMW agents should be increased on separate days, because this type of agent can induce isolated LARs.

The intensity of exposure may also be gradually increased, although we recently demonstrated that increasing the concentration of isocyanates is unnecessary, provided that the subjects are exposed for long enough [30]. Furthermore, exposure to low concentrations is likely to prevent the occurrence of nonspecific irritant reactions. For HMW agents, the initial concentration can be drawn from the results of skin-prick tests and baseline NSBHR, as the concentration of allergen capable of causing an early reaction is directly related to the degree of immunological sensitization of the subject and the level of NSBHR [17]. The relationship between the level of baseline NSBHR and the development of asthmatic reactions to LMW agents has been less precisely characterized (see section on pathophysiology of asthmatic reaction determinants of asthmatic reactions).

It remains uncertain how long a subject should be exposed before SIC can be considered negative, because specific bronchial responsiveness to occupational agents may decline when the subject is removed from exposure [31-36]. However, a recent prospective study indicates that specific bronchial responsiveness almost never completely disappears, although a longer challenge exposure to the causal agent may be necessary to produce an asthmatic reaction after removal from the workplace of 2 yrs or more [36]. Most subjects with OA react after exposure for $2 \mathrm{~h}$, but exposure for up to $4 \mathrm{~h}$ may be required to induce a bronchial response [28]. As discussed below, post-challenge increase in NSBHR means that further challenge is required before excluding OA [37].

\section{Assessment of bronchial response}

Airway calibre. Airway calibre can be assessed by using various indices [38]. Assessment of expiratory volumes and flows generated during a maximal forced-expiratory manoeuvre, including $\mathrm{FEV} 1, \mathrm{PEF}$, and maximal midexpiratory flow rates (MMEF) are preceded by a 


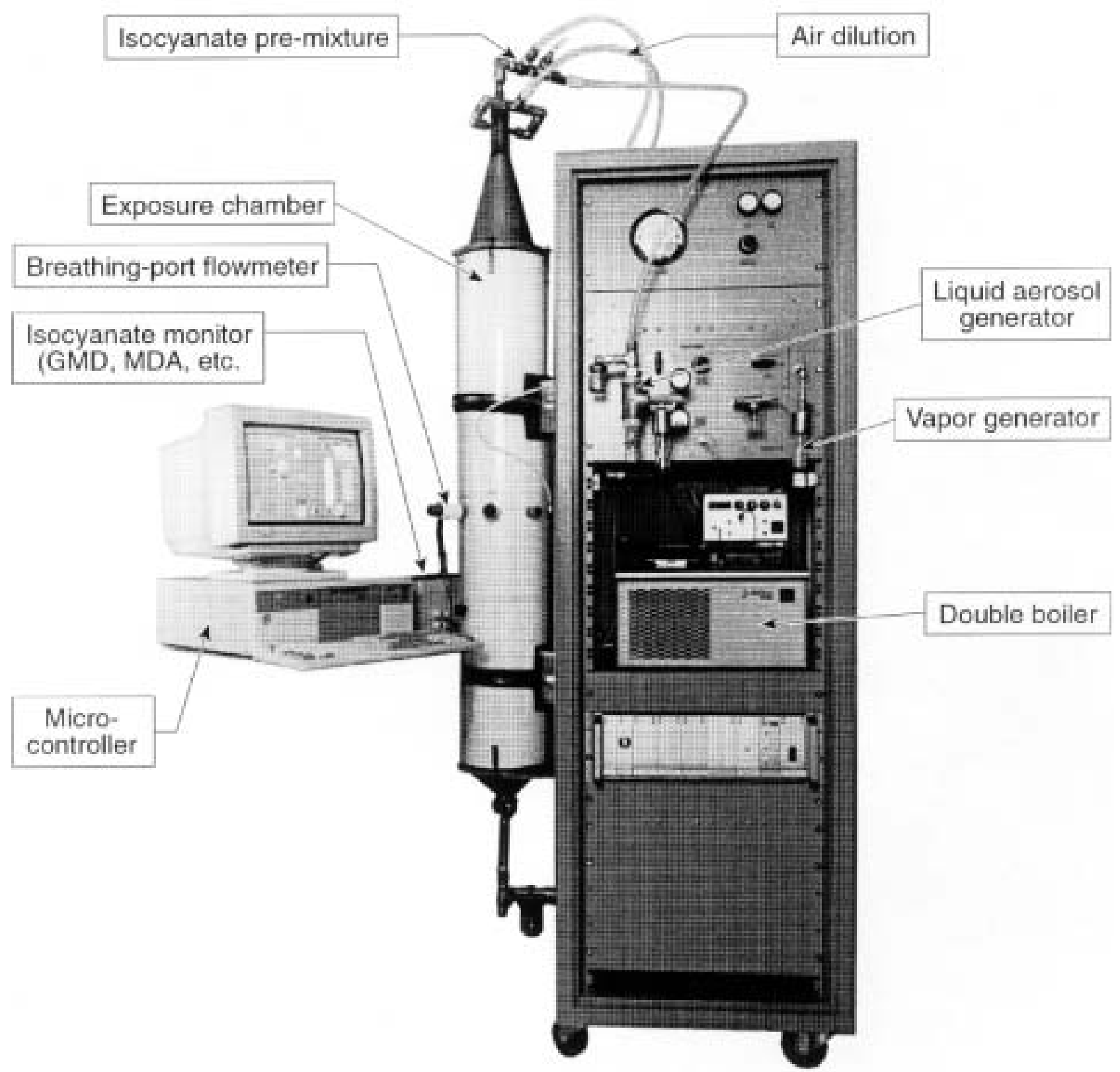

Fig. 1. - Closed-circuit apparatus for inhalation challenges with isocyanates. GMD: GMD Systems Inc., Pittsburgh, PA, USA; MDA: MDA Scientific, Glenview, IL, USA.

deep inspiration that can cause either bronchodilation or bronchoconstriction [39-41]. FEV1 remains the gold standard parameter for assessing bronchial response in clinical practice, because it is generally easily performed by the subject under a technician's supervision, and is highly reproducible [38]. PEF is more effort-dependent than FEV1 and reflects predominantly the changes in proximal airways. Although PEF is less sensitive than FEV1 in detecting asthmatic reactions [42], it can be a useful tool for assessing changes in airway calibre, when the subject has left the laboratory. The MMEF (forced midexpiratory flow (FEF25-75\%)) is sensitive in detecting minimal airflow limitation [43], but it is less reproducible than FEV1 [44] and can be difficult to interpret when the vital capacity varies. It should not be routinely used for assessing induced bronchodilation and bronchoconstriction [38].
The effects of deep inspiration can be avoided by measuring specific airway conductance at tidal breathing in a body plethysmograph or by the use of partial flow-volume curves. Changes in specific airway conductance seem to occur earlier than changes in FEV1 during induced bronchoconstriction [43]. However, these indices have a higher spontaneous variability and are less reproducible than FEV1 [44].

Nonspecific bronchial hyperresponsiveness. A number of studies have documented that asthmatic reactions induced by sensitizing agents can be associated with an increase in NSBHR that may persist for several hours to several weeks [45-52]. This increase in NSBHR may help to distinguish asthmatic reactions due to specific hyperresponsiveness mechanisms from nonspecific bronchoconstriction triggered by irritants. Furthermore, 
there is evidence that such an increase in NSBHR may precede the occurrence of an asthmatic reaction to occupational agents in subjects who are challenged after leaving their workplace $[37,53]$. It has recently been demonstrated that post-challenge changes in NSBHR represent early and sensitive markers of bronchial response to occupational agents (fig. 2) [37]. The level of NSBHR should be systematically assessed after SIC in the absence of airway calibre changes. Significant increases in post-challenge NSBHR indicate the need for additional challenge exposures in the laboratory and/or in the workplace before excluding a diagnosis of OA. The optimal timing for assessing post-challenge changes in NSBHR remains to be determined by further investigation.

Other parameters. Body temperature and peripheral blood leukocytosis should be systematically assessed. Increases in body temperature $\left(>37.2^{\circ} \mathrm{C}\right)$ and leucocyte count $\left(>2,500\right.$ cells $\left.\cdot \mathrm{mm}^{-3}\right)$ associated with a fall in forced vital capacity (FVC) are more sensitive than changes in diffusing capacity and radiographic infiltrates in detecting the systemic and "alveolar" responses of extrinsic allergic alveolitis [54, 55]. A retrospective analysis of 317 subjects with OA confirmed by positive SIC in terms of spirometry showed that fever was recorded in $15(5 \%)$ subjects and was associated with an increase in blood neutrophils and a decrease in FVC [56]. Fever occurred more frequently during LAR or atypical reactions induced by LMW agents. An increase in peripheral blood eosinophil count can be observed after LAR [57].

Post-challenge bronchoalveolar lavage (BAL) can be used to confirm the diagnosis of extrinsic allergic alveolitis by demonstrating an early influx of neutrophils and a subsequent increase in suppressor and cytotoxic lymphocytes [58]. Furthermore, alveolitis, as assessed by BAL, may be documented in the absence of changes in diffusing capacity or radiological evidence of parenchymal involvement [55].

Schedule of monitoring. FEV1 should be measured every 10-15 $\mathrm{min}$ for the first hour, every $30 \mathrm{~min}$ for the second hour, and then hourly for a total of at least $8 \mathrm{~h}$ after the end of exposure [13]. PEF is monitored hourly during the day, as well as during the evening until bedtime, and at night if the subject is awakened by symptoms. Body temperature should be assessed hourly to detect systemic responses.

Interpretation of results. In clinical practice, SICs are generally considered positive when there is a sustained fall in FEV1 of more than $20 \%$ from prechallenge value in the absence of significant $(>10 \%)$ changes after exposure to a control product [13]. Statistical methods comparing the changes in FEV1 on a challenge day to those observed on control days have recently been proposed to increase the sensitivity in detecting LAR [59]. Such statistical approaches, however, have major practical limitations, as they require serial measurements of FEV1 on several (at least three) control days in order to obtain an adequate estimate of the day-to-day variability. Further information is required to determine whether reproducible increases in NSBHR should be regarded as reflecting significant bronchial response to occupational agents a)

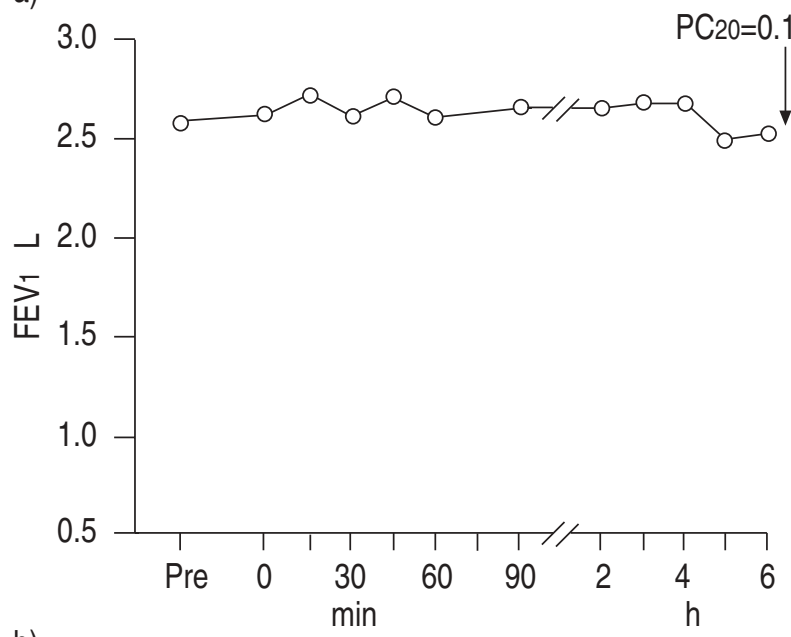

b)
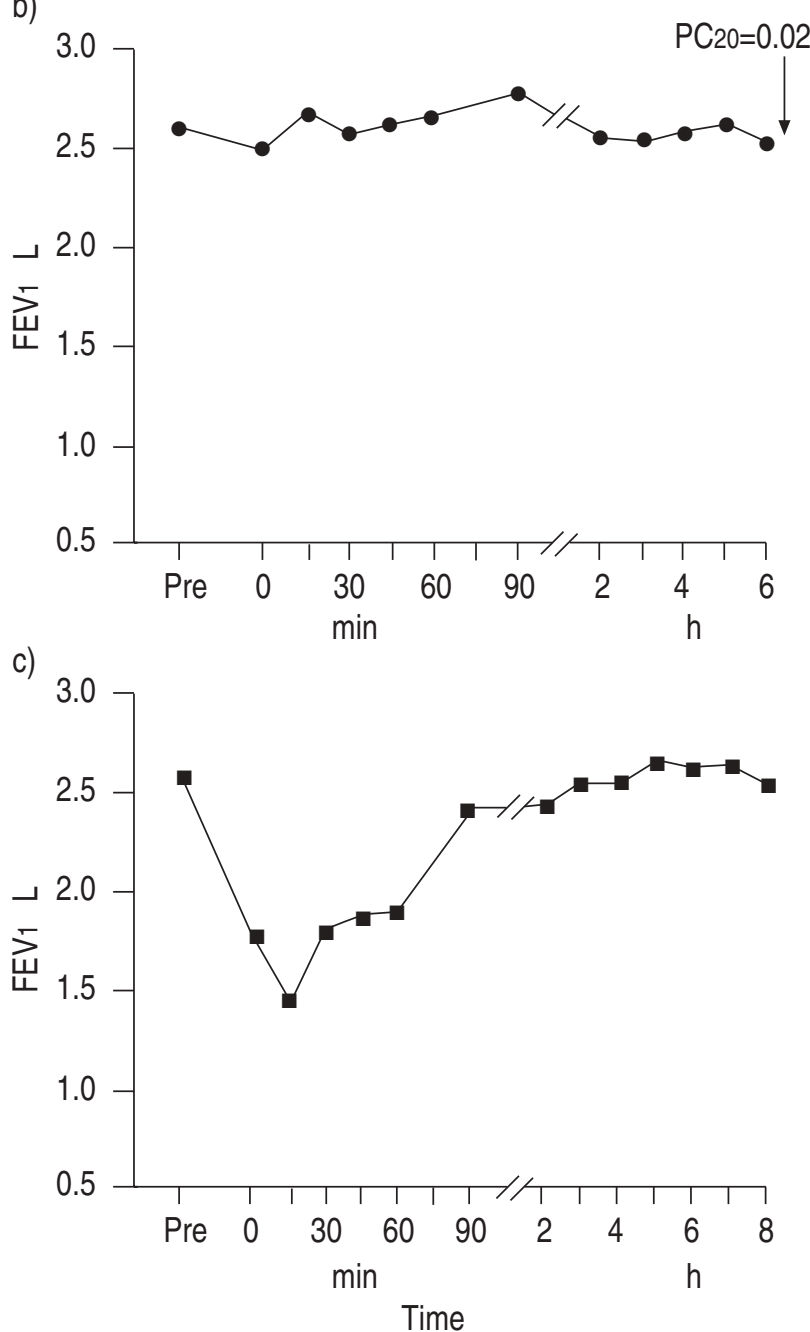

Fig. 2. - The changes in forced expiratory volume in one second $\left(\mathrm{FEV}_{1}\right)$ and nonspecific bronchial hyperresponsiveness expressed as the provocative concentration of histamine causing FEV 1 to fall by $20 \%$ (PC20,hist) during a specific inhalation challenge in a hairdresser who had been removed from her workplace for 2 yrs, are presented. a) On a control day, the subject was exposed to lactose powder. Baseline PC20,hist was $0.1 \mathrm{mg} \cdot \mathrm{mL}^{-1}$. b) Exposure to persulphate for 2 $\mathrm{h}$ on the first test day did not induce significant changes in FEV1, but baseline $\mathrm{PC} 20$,hist fell from 0.1 to $0.02 \mathrm{mg} \cdot \mathrm{mL}^{-1}$. c) Ex-posure to persulphate for 20 mins on the second test day elicted an immediate asthmatic reaction. (Reproduced, with permission, from [37]). 
when decrements in FEV1 do not fulfil the recommended criteria.

SIC can induce EAR, LAR or dual asthmatic reactions (DARs). During EAR, maximal fall in FEV1 is recorded within the 10-20 min following exposure, and airway calibre returns to normal within 60-120 min. LAR occurs 3-8 h after exposure. DAR is a combination of an EAR and an LAR with recovery of bronchial obstruction (FEV1 $\geq 90 \%$ of baseline value) between the two components of the response. Besides these classical patterns, atypical reactions have recently been outlined [60]. Prolonged immediate reactions are similar to EAR, but with a slower recovery of FEV1 over several hours. Progressive reactions are characterized by a progressive fall in FEV1 starting at the end of exposure and worsening for up to several hours. Square-waved reactions are similar to DAR, but without significant recovery between the immediate and late components of the reactions.

\section{Pitfalls}

Adverse reactions. SICs carry only minimal risk as long as safety requirements are stringently respected, duration/intensity of exposure is increased progressively, and bronchial response is carefully monitored. More than 1,500 SICs have been performed in a specialized centre in Montreal, Canada, with only one acute severe reaction requiring temporary mechanical ventilation and with complete recovery, at a time when special apparatus allowing a more suitable control of concentration was not available [61].

SICs have been documented as inducing exacerbation of asthma with recurrent nocturnal symptoms for a few days [62-64]. This, however, should not be considered different from recurrent asthma that can result from workplace exposure. It is our experience that only about $5 \%$ of subjects with positive SIC experience mild and transient worsening of their asthma for 2-3 days. For those subjects who demonstrate LAR or DAR, initiating or increasing inhaled steroids for a few days is indicated. Cutaneous and anaphylactoid reactions have occasionally been described $[65,66]$.

SIC can induce the development of sensitization to occupational agents in technicians who perform the procedure. Closed-circuit delivery systems [19-21, 28] make it possible to substantially reduce the health hazards for staff members.

Ethical issues. SICs are often discussed on ethical grounds, clearly an important consideration when performing these tests for research purposes. However, regarding SIC in clinical practice, Pepys and HutchCroft [10] gave the following outline: "One of the primary obligations of the clinician in asthma, as in any other disease, is to make a precise aetiological diagnosis. This is particularly relevant to allergic disorders, in which avoidance of the causative agent may terminate or reduce the disorder... Failure to do the tests (SIC) could be regarded as an act of omission". The possibility of inducing sensitization in workers by SIC is sometimes raised as an ethical question, but it can be argued that the usual workplace exposure is much more prolonged than that found in an SIC context.
False-negative results. SIC may lead to false-negative results when: 1) the subject has not been tested with the agent that actually caused OA; or 2) the subject has been absent from work for a long period of time, leading to a decreased specific bronchial responsiveness to the causal agent. These problems can be overcome by taking a careful occupational history, by exposing the subject for prolonged periods, and by assessing postchallenge changes in NSBHR [37]. Falsely-negative SIC due to complete loss of bronchial responsiveness to an occupational agent is a rare occurrence [36]. When SIC is negative, provision should be made to return the subject to the workplace while monitoring PEF. If PEF is difficult to interpret or suggests OA, provisions should be obtained to monitor the functional parameters during one or two workshifts, by sending a technician to the workplace.

False-positive results. False-positive reactions, i.e., nonspecific bronchoconstriction due to an irritant effect, can occur in subjects with marked NSBHR or unstable asthma. Such irritant reactions (which do not fall within the definition of OA) cannot easily be distinguished from immediate hypersensitivity reactions. These reactions could be prevented by exposing the subjects to concentrations below the TLV. The presence of a stable functional state can be verified by monitoring FEV1 during a control test. The occurrence of irritant reactions can be detected by exposing the subjects to a control product. An increase in NSBHR after an asthmatic reaction provides further evidence that airway obstruction results from specific hyperresponsiveness. If required, the specificity of the reaction can be verified by testing control asthmatic subjects in the same conditions after obtaining their informed consent.

\section{Roles of SIC}

\section{Clinical purposes}

Diagnosis of $O A$. OA is becoming the principal cause of work-related respiratory ailment in industrialized countries, accounting for $26-50 \%$ of new cases of occupational lung disease [67-70]. Estimates of the annual incidence of OA range 20-140 per million workers [70]. The importance of reliability when diagnosing OA becomes evident when one considers the impact, both medical and socioeconomic, of such a diagnosis. Follow-up studies have shown that subjects with OA should be completely and definitively removed from exposure to the causal agent to avoid further deterioration of asthma $[71,72]$. Advising a subject to leave work and retrain for another job has a considerable financial and social impact [73-76]. Therefore, the consequences of either diagnosing OA when it is not present, or of missing the diagnosis when it is present, are substantial. Furthermore, reliable diagnosis and precise identification of the causal agent are required to implement appropriate preventive strategies [77].

Diagnosing OA cannot be based solely on documenting the presence of asthma and workplace exposure to agents known to cause asthma, because both are common occurrences in the general population. A number of diagnostic procedures can be used to assess OA [78]. 
These tests should be combined in a stepwise approach (fig. 3). The clinical history is sensitive but lacks specificity in diagnosing OA [79]. This is because exposure to irritants in the workplace is likely to trigger symptoms in subjects with asthma, simulating true OA. However, this conclusion was reached in a study conducted in subjects who consulted for this condition, in a country where OA is well compensated, thus making it less likely that patients would have masked their symptoms. NSBHR may be absent in a substantial proportion of subjects with OA (e.g., 17-45\% in isocyanate-induced OA) $[80,81]$, particularly when they are evaluated after removal from exposure. However, the absence of NSBHR, when assessed shortly (within hours) after a workshift, virtually excludes a diagnosis of OA. Immunological tests can be useful to demonstrate sensitization to occupational agents. However, the major problem is that extracts of occupational agents are not standardized for in vivo and in vitro testing and can only be used for HMW agents causing OA through an IgE-dependent mechanism. Furthermore, positive immunological tests do not necessarily imply that the target organ (i.e., the bronchi) is involved, since specific IgE antibodies can be present in a substantial proportion of exposed workers without OA. On average, immunological tests for HMW agents may be regarded as having a sensitivity of about $95 \%$ and a specificity of about $85 \%$ [82-87]. Among subjects investigated for $\mathrm{OA}$ due to an HMW agent, the post-test probability of having OA is $90 \%$ when the subject has a history suggestive of OA, NSBHR, and positive immunological tests. Thus, even when immunological tests are available (and reasonably reliable), we are left with a $10 \%$ rate of false-positive diagnoses. Specific $\mathrm{IgE}$ antibodies directed against LMW agents can be detected, but usually within a much smaller percentage of workers with OA [8, 23, 88-91]. At this stage, immunological tests should not be used to confirm or exclude a diagnosis of OA due to LMW agents.

The causal relationship between exposure to an occupational agent and asthma can be established on an individual basis using either PEF monitoring at work, SIC in the laboratory or surveillance of spirometry under the supervision of a technician during a day at work. The advantages and practical limitations of PEF recording have recently been reviewed [92]. Prospective studies have found that PEF monitoring has a sensitivity of $81-89 \%$ and a specificity of $74-89 \%$ in diagnosing OA as compared with SIC [15, 93]. Combining PEF monitoring with assessment of work-related changes in NSBHR has been proposed; this increases sensitivity only slightly [84-92\%], but decreases specificity [61$67 \%$ ], as compared with PEF alone [15, 93].

SIC in the laboratory remains the most reliable and straightforward means to establish the diagnosis of OA. SICs are indicated in every instance where the subject has left or lost his/her job by the time of assessment, and cannot return to work even on a trial basis. SIC should also be regarded as the first line-procedure when: 1) a diagnosis of OA has to be confirmed or excluded without delay; 2) exposure to the workplace has been reported to induce severe asthmatic reactions; 3 ) the causal agent has to be precisely identified in order to implement appropriate preventive strategies; or 4) the suspected agent has never been reported as causing OA. Finally, SIC should be preferred to PEF monitoring in confirming or excluding OA whenever hospital facilities and the expertise to perform such tests are available.

PEF monitoring can be used as a first-screening test in establishing the work-relatedness of airflow limitation. These tests are of special interest when: 1) the facilities and expertise for SIC are not available; 2) an agent known to cause OA has not been identified in the subject's workplace; or 3) the subject is exposed to multiple agents that are known as potential asthma inducers.
Fig. 3. - The stepwise approach to diagnosing occupational asthma. NSBHR: nonspecific bronchial hyperresponsiveness; PEF: peak expiratory flow rate; SIC: specific inhalation challenge. $*$ : assessed at the end of a workshift and a minimal period of 2 weeks at work. 
Workplace monitoring of spirometry under the supervision of a technician should be considered when: 1) SIC cannot be performed reliably in the laboratory because the agent causing asthma has not been identified or the process that induces asthma at work cannot be reproduced adequately in the hospital setting; or 2) SIC in the laboratory is negative while monitoring of PEF demonstrates reproducible changes related to workplace exposure. In these instances, FEV1 is recorded in the workplace using a portable spirometer under the close supervision of a technician or physician. A control test day should be performed in the laboratory using the same apparatus in order to ensure that changes in FEV1 are actually related to the workplace. Workplace inhalation challenges have practical limitations, as it may be difficult to obtain the employer's authorization and to perform the tests under the working conditions that prevailed when the subject experienced asthma. In addition, functional monitoring in the workplace is time-consuming and expensive, as a technician is required for a single test.

Case ascertainment in epidemiological surveys. Epidemiological studies are primarily concerned with quantifying the occurrence of disease, determining exposure-response relationships, and identifying associated risk factors [94]. The definition of OA in epidemiological studies varies according to the circumstances and objectives of the study, since a simple and specific test for the identification of OA does not exist. Estimates of prevalence among workers in high-risk occupations are largely affected by the criteria used for defining OA. The wide range of prevalence figures obtained using different diagnostic criteria are presented in tables 1 and 2 , which summarize the results of surveys conducted among workers exposed to LMW [95-102] and HMW agents [32, 83, 103-107].

Standardized questionnaires are sensitive but not specific in identifying workers with OA [108]. This can be explained by the fact that a high proportion of workers exposed to dusty workplaces experience nonspecific respiratory symptoms at work. The specificity of questionnaires can be higher in less dusty environments [106]. Immunological testing can be used to provide evidence of sensitization to occupational agents acting through an IgE-mediated mechanism. Skin-prick tests are easy to perform in field studies, inexpensive, well accepted, and safe. Blood samples can be obtained for determination of specific IgE antibodies, although this technique seems to be less specific than skin tests in identifying OA $[32,83,103,104]$. Measurement of NSBHR has been used safely in epidemiological studies. Abbreviated methods that take no longer than $30 \mathrm{~min}$ and can be performed in field studies have been described [109-111]. However, assessment of NSBHR is not specific enough to identify $\mathrm{OA}$, and should be used in combination with other tests. Comparison of NSBHR before and after a period of exposure at work may be useful when exposure to the agent suspected of causing OA is intermittent $[32,83,101]$.

Only a few surveys of OA have used a case ascertainment procedure based on the objective assessment of the relationship between asthma and exposure to occupational agents (tables 1 and 2). Assessment of crossshift change in FEV1 is a valuable method for detect- ing respiratory effects of workplace exposure on a workforce as compared with a nonexposed population, but it is not reliable for the identification of individual workers with OA [112]. Monitoring of PEF at work has been used to assess the work-relatedness of airway obstruction in epidemiological studies of OA $[32,97,99,101$, 102]. Although the reproducibility of the interpretation of PEF records is good [113], the procedure has practical pitfalls that limit its use as a screening procedure in large populations of workers: the compliance in recording PEF is usually below $60 \%$ [32, 83, 99]; the interpretation of approximately $25 \%$ of complete records remains uncertain $[83,99]$; it may be difficult to obtain records for long enough periods away from work to exclude OA; and there is evidence that PEF monitoring can be negative in a substantial number of subjects with OA demonstrated by a positive SIC $[83,99,101]$. Although SICs are not suitable for field studies on large populations, they should be used as a final step to confirm the diagnosis in subjects suspected of having OA based on screening procedures.

Although diagnostic tests should be selected depending on available resources and the degree of certainty with which the investigator wants to establish OA, increasing the reliability of OA identification will undoubtedly increase the accuracy of the information drawn from the study. To achieve these ends, case ascertainment should follow a stepwise procedure (fig. 4). An initial survey of all exposed workers should be conducted to identify the presence of features suggestive of OA. A second survey should be conducted on all potential cases, and ideally on a sample of the underlying population, to ascertain the presence of OA. The initial field screening should include tests that are easily performed, well accepted, and highly sensitive. All exposed workers should be given a standardized questionnaire, as well as immunological testing (skin-prick tests) when the suspected agent causes OA through an IgE-mediated mechanism. Assessment of NSBHR can be restricted to subjects with symptoms suggestive of OA and/or positive immunological tests. When reliable immunological tests are not available, assessment of NSBHR can be included in the initial survey. Further investigations for definitive confirmation of OA should be carried out in subjects who report work-related symptoms suggestive of OA and NSBHR, as well as in subjects who show evidence of immunological sensitization. This final step includes monitoring of PEF or, preferably, SIC or serial monitoring of spirometry at work under supervision by a technician [32].

Surveillance programmes. As is the case for clinical and epidemiological assessment, screening programmes for OA can use several procedures, including questionnaires, immunological tests, and assessment of NSBHR. However, definitive confirmation of $\mathrm{OA}$ is crucial for the precise identification of the causal agent and the implementation of appropriate preventive measures (i.e., relocation of affected workers to an unexposed job and improved control of exposure) [72]. In such a context, SIC can play an important role in screening and surveillance programmes of exposed workforces. The initial tests can be sensitive but only poorly specific for OA, provided that false-positive results will be identified at 
Table 1. - Prevalence estimates of occupational asthma according to diagnostic criteria in surveys of workers exposed to low molecular weight agents.

\begin{tabular}{|c|c|c|c|c|c|c|c|c|c|c|c|c|}
\hline \multirow[b]{2}{*}{ Agent/occupation } & \multicolumn{2}{|c|}{ Questionnaire } & \multicolumn{2}{|c|}{ NSBHR } & \multicolumn{2}{|c|}{ SPT } & \multicolumn{2}{|c|}{ Specific IgE } & \multicolumn{3}{|c|}{ Case identification } & \multirow[b]{2}{*}{ [Ref.] } \\
\hline & $\mathrm{n}$ & $\%$ & $\mathrm{n}$ & $\%$ & $\mathrm{n}$ & $\%$ & $\mathrm{n}$ & $\%$ & $\mathrm{n}$ & $\%$ & Procedures & \\
\hline $\begin{array}{l}\text { MDI/foundry } \\
\text { workers }\end{array}$ & $\mathrm{NA} / 78$ & & $\mathrm{NA} / 78$ & & ND & & $2 / 76$ & 3 & $\begin{array}{l}12 / 78 \\
1 / 78\end{array}$ & $\begin{array}{c}15 \\
1\end{array}$ & $\begin{array}{c}\text { Q+NSBHR } \\
\text { Q+IgE }\end{array}$ & [95] \\
\hline $\begin{array}{l}\text { MDI/spray } \\
\text { painters }\end{array}$ & $9 / 51$ & 18 & $\begin{array}{c}10 / 10 \\
(\mathrm{Q} \text { or FEV }\end{array}$ & $\begin{array}{l}20 \\
1<80 \%)\end{array}$ & ND & & ND & & $\begin{array}{c}9 \\
6 / 10\end{array}$ & $\begin{array}{l}18 \\
12\end{array}$ & $\begin{array}{c}\mathrm{Q}+\mathrm{NSBHR} \\
\text { SIC }(\mathrm{Q} \text { or NSBHF}\end{array}$ & $\begin{array}{l}{[96]} \\
\text { IR) }\end{array}$ \\
\hline MDI/mold paint & $35 / 243$ & 14 & $\begin{array}{l}6 / 7 \\
(\mathrm{PEF})\end{array}$ & 2 & $1 / 71$ & 1 & $2 / 243$ & 1 & $\begin{array}{c}7 / 66 \\
3 \\
2 \\
0\end{array}$ & $\begin{array}{l}3 \\
1 \\
1 \\
0\end{array}$ & $\begin{array}{c}\mathrm{PEF} \\
\mathrm{Q}+\mathrm{PEF} \\
\mathrm{Q}+\mathrm{PEF}+\mathrm{NSBHR} \\
\mathrm{Q}+\mathrm{IgE}\end{array}$ & $\begin{array}{l}\text { [97] } \\
\mathrm{R}\end{array}$ \\
\hline $\begin{array}{l}\text { Phthalic anhydride/ } \\
\text { resin production }\end{array}$ & $6 / 48$ & 13 & $7 / 30$ & 15 & $2 / 30$ & 7 & ND & & $\begin{array}{c}3 \\
2 \\
2 \\
2 / 2\end{array}$ & $\begin{array}{l}6 \\
4 \\
4 \\
4\end{array}$ & $\begin{array}{c}\mathrm{Q}+\mathrm{NSBHR} \\
\mathrm{Q}+\mathrm{SPT} \\
\mathrm{Q}+\mathrm{NSBHR}+\mathrm{SPT} \\
\mathrm{SIC}(\mathrm{Q}+\mathrm{NSBHR}+\mathrm{S}\end{array}$ & $\begin{array}{l} \\
\quad[98] \\
\text { T } \\
\text { SPT) }\end{array}$ \\
\hline $\begin{array}{l}\text { Persulphates salts/ } \\
\text { hairdressers }\end{array}$ & $4 / 23$ & 17 & $7 / 23$ & 30 & $1 / 14$ & 4 & ND & & $\begin{array}{c}4 \\
1 / 12 \\
4 / 17\end{array}$ & $\begin{array}{c}17 \\
4 \\
17\end{array}$ & $\begin{array}{c}\text { Q+NSBHR } \\
\text { PEF } \\
\text { SIC }\end{array}$ & [99] \\
\hline $\begin{array}{l}\text { Reactive dyes/ } \\
\text { dye industry }\end{array}$ & $78 / 309$ & 25 & $\begin{array}{c}38 / 78 \\
(\mathrm{Q})\end{array}$ & 12 & NA & & $57 / 309$ & 18 & $\begin{array}{c}23 \\
13 / 20\end{array}$ & $\begin{array}{l}7 \\
4\end{array}$ & $\begin{array}{c}\mathrm{Q}+\mathrm{IgE} \\
\text { SIC }(\mathrm{Q}+\mathrm{NSBHR})\end{array}$ & R) \\
\hline $\begin{array}{l}\text { Spiramycin/ } \\
\text { pharmaceuticals }\end{array}$ & $9 / 48$ & 19 & $6 / 43$ & 12 & ND & & ND & & $\begin{array}{c}7 / 42 \\
0 / 48 \\
3 \\
3 \\
14 \\
3 / 12\end{array}$ & $\begin{array}{c}15 \\
0 \\
6 \\
6 \\
29 \\
6 \mathrm{~S}\end{array}$ & $\begin{array}{c}\Delta \mathrm{NSBR} \\
\mathrm{PEF} \\
\mathrm{Q}+\mathrm{NSBHR} \\
\mathrm{Q}+\Delta \mathrm{NSBHR} \\
\mathrm{Q}+\mathrm{NSBHR} \text { or } \Delta \mathrm{NSB} \\
\mathrm{IC}(\mathrm{Q}+\mathrm{NSBHR} \text { or } \Delta \mathrm{NS}\end{array}$ & $\begin{array}{l}\text { BHR } \\
\text { SBHR) }\end{array}$ \\
\hline $\begin{array}{l}\text { Eastern white } \\
\text { cedar/sawmill }\end{array}$ & $25 / 42$ & 60 & $15 / 41$ & 36 & ND & & ND & & $\begin{array}{c}12 \\
3 / 12\end{array}$ & $\begin{array}{c}29 \\
7\end{array}$ & $\begin{array}{c}\mathrm{Q}+\mathrm{NSBHR} \\
\text { SIC }(\mathrm{Q}+\mathrm{NSBHR})\end{array}$ & [102] \\
\hline
\end{tabular}

NSBHR: nonspecific bronchial hyperresponsiveness; SPT: skin-prick tests; IgE: immunoglobulin E; MDI: diphenylmethane diisocyanate; FEV1: forced expiratory volume in one second; SIC: specific inhalation challenge; PEF: peak expiratory flow rate; ND: not done; NA: data not available; $\triangle \mathrm{FEV} 1$ : work-related decrease in FEV1; $\triangle \mathrm{NSBHR}$ :work-related increase in NSBHR; n: number of positive tests/number of subjects tested. The features used to select the tested subjects are indicated in parenthesis where appropriate. Prevalence rates have been estimated by using the number of subjects who responded to the questionnaire as the denominator. The surveys have been selected on the following criteria: number of studied subjects $\geq 20$ and diagnostic tests including: 1) a questionnaire (Q); 2) immunological testing or assessment of NSBHR; and 3) SIC or PEF monitoring.

the stage of the definitive investigation. SIC should, therefore, be considered as the final, confirmatory step in screening and surveillance programmes.

In epidemiological studies, SICs have been found to induce asthmatic reactions in subjects who show evidence of immunological sensitization to occupational agents and NSBHR, although they do not report symptoms suggestive of OA [104, 106]. These observations suggest that some subjects may have latent or preclinical occupational asthma, which can be revealed only after sufficiently high or prolonged exposure to the sensitizing agent or, alternatively, that these subjects are poor sensors of their symptomatology. Although the outcome of those subjects with preclinical OA is unknown and warrants prospective investigation, we believe that it is relevant to identify such subjects, since persistence of exposure would result in progressive worsening of NSBHR, leading to clinically evident asthma and possibly to permanent disability. SIC could, therefore, be useful to identify subjects with OA at an early, preclinical stage.

Assessment of preventive procedures. Immunochemical methods have been used to quantify the reduction of the level of airborne allergens achieved by preventive procedures, such as improved housing conditions for laboratory animals [114] and the use of "low-allergen" latex gloves [115]. However, standardized in vitro methods for quantitative assessment of HMW allergens are not available as routine procedures. Furthermore, it remains uncertain whether the results of in vitro assessments correlate with the in vivo effects of HMW agents, which are often complex antigenic materials. Therefore, SIC performed in subjects with OA could represent a useful in vivo model for investigating the effectiveness of preventive procedures aimed at reducing the level of exposure to causal agents, although they have only seldom been used for that purpose. The procedure has been proposed to evaluate the respiratory effects on exposure to different formulations of the plant ispaghula which is contained in bulk laxatives, in nurses and pharmaceutical workers who exhibit asthma and/or rhinitis on exposure to this plant [116]. The bronchial response to latex gloves with a low protein content has been evaluated using SIC in healthcare workers with latexinduced OA [117]. Low-protein latex gloves significantly reduced the risk of developing an asthmatic reaction in subjects with OA due to latex, although highly sensitive subjects may still develop asthma after prolonged exposure. This study showed that SIC can be a useful initial guide for implementing preventive procedures on an individual basis, although the effects of long-term exposure should be carefully investigated using PEF monitoring at work as well as serial assessments of NSBHR. Combining SIC with quantitative assessment of airborne HMW agents could help to determine the 
Table 2. - Prevalence estimates of occupational asthma according to diagnostic criteria in surveys of workers exposed to high molecular weight agents.

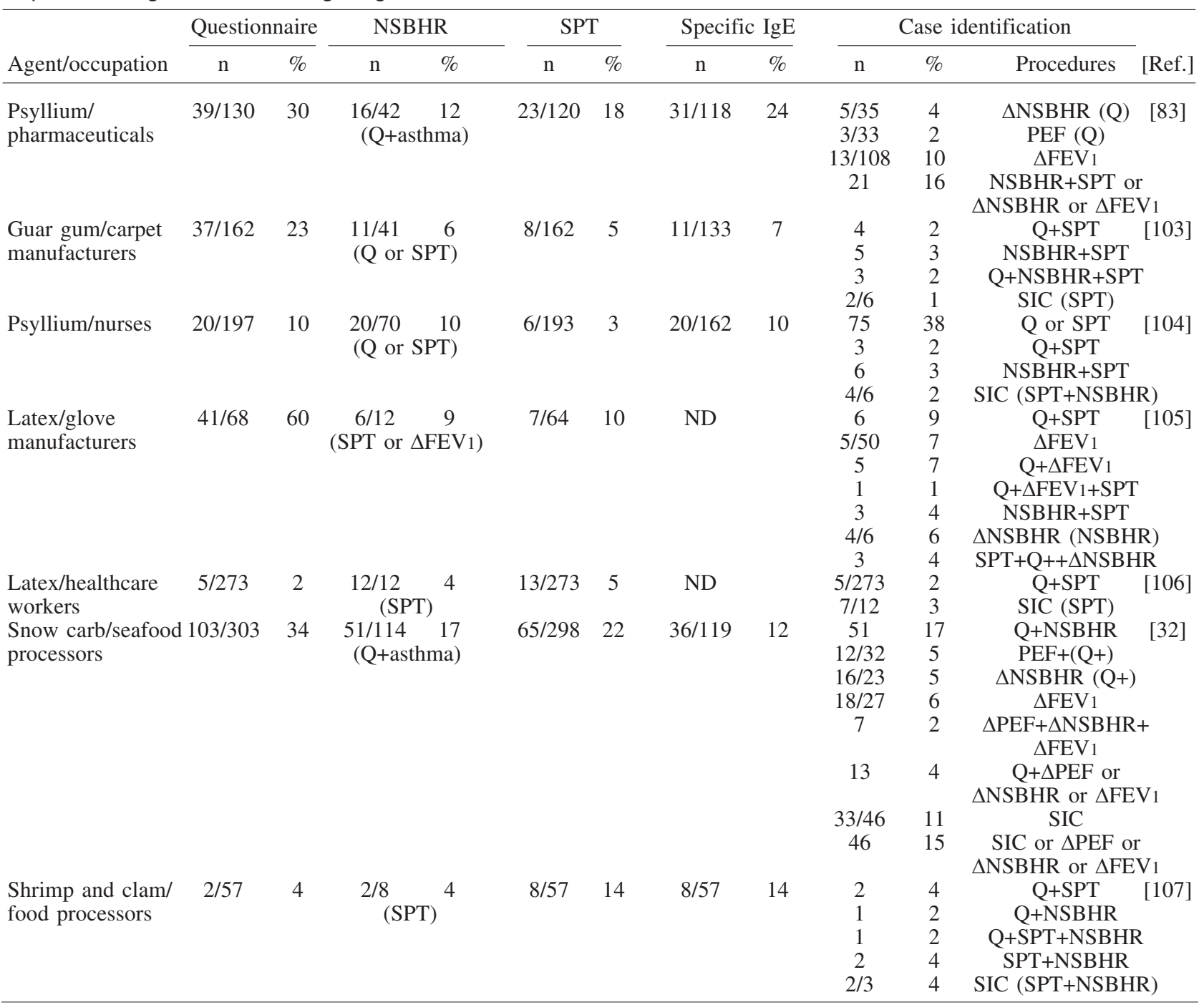

For definitions see legend to table 1.

level that elicits reactions in already sensitized subjects; the results could then be used as a guide to establish permissible exposure levels at work.

SIC in the laboratory under controlled conditions should also be regarded as the most appropriate procedure to evaluate the efficacy of personal protective devices. At present, only a few investigators have monitored PEF at the workplace to assess protective devices in subjects sensitized to laboratory animals [118] and in aluminium potroom workers [119]. Surprisingly, SICs have not yet been used for that purpose.

\section{Research purposes}

Pathophysiology of asthmatic reactions. SIC has been widely used to investigate the pathophysiological mechanisms of asthmatic reactions caused by HMW allergens and LMW occupational agents.

Determinants of asthmatic reactions. SIC led to the early recognition of different patterns of asthmatic reactions $[2,10]$. Of these, LARs were later found to be particularly relevant to the pathophysiology of asthma, being associated with an increase in NSBHR and acute inflammatory events in the airways. More recently, atypical patterns of reactions have been recognized [60]. These atypical reactions occur more frequently after SIC with isocyanates, although their pathophysiological relevance remains uncertain.

Although it was initially proposed by TIFFENEAU [16], COCKCROFT et al. [17] were the first to derive a formula aimed at the identification of the concentration of an HMW common allergen causing an immediate $20 \%$ fall in FEV1 (PC20,allergen); this is determined by the degree of immunological sensitization of the subject and the level of NSBHR. Information is scarce regarding the factors capable of influencing the development of bronchial response induced by LMW occupational agents that do not act through an IgE-dependent mechanism. BURGE [81] found that the dose of TDI required to induce an asthmatic reaction in sensitized subjects correlated with the level of baseline responsiveness to histamine. Using the closed-circuit apparatus described above [28], it has been shown that the cumulative dose 


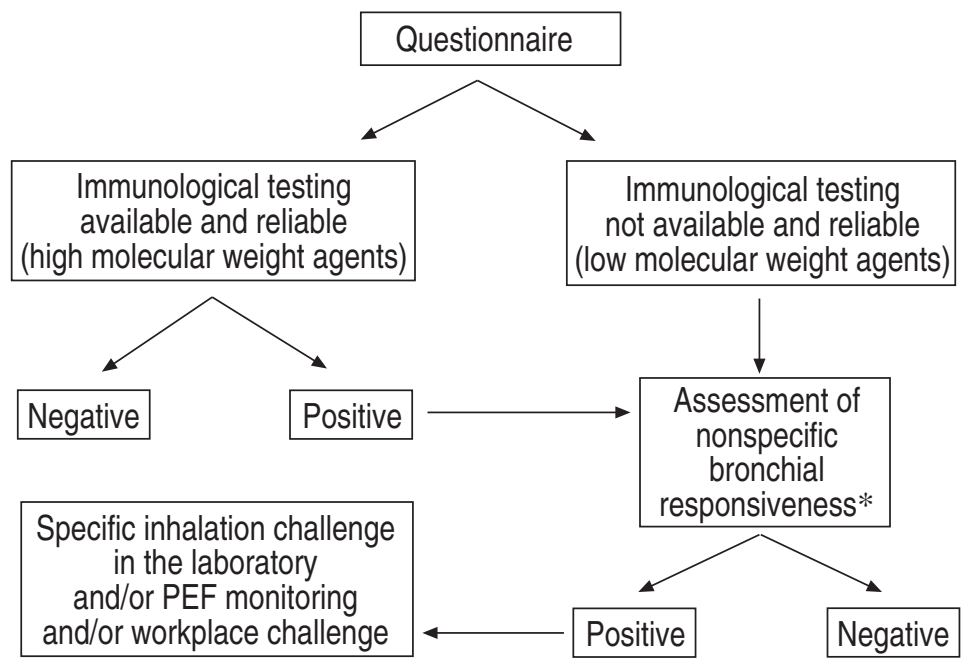

Fig. 4. - The stepwise approach for case ascertainment in epidemiological surveys of occupational asthma. PEF: peak expiratory flow rate; *: assessment at the end of a workshift.

of inhaled isocyanate is the main determinant of the occurrence of an asthmatic reaction in a given subject [30].

The factors associated with the development of LAR to HMW allergens include: the degree of immunological sensitization; the level of bronchial responsiveness to the allergen; the level of NSBHR; and the dose of allergen inhaled [120-125]. Interestingly, LARs occur more frequently, are more severe, and are associated with more prolonged changes in NSBHR after allergen exposure in the evening, than after a similar exposure in the morning [126]. The factors that determine the pattern of bronchial response to LMW agents remain uncertain. PAGgiaro et al. [127] found that the development of DAR induced by isocyanates was associated with more severe OA, as assessed by the duration of symptoms, baseline airway obstruction, and level of NSBHR. Several studies have documented that repeated exposure to LMW agents can induce changes in the pattern of reaction from isolated LAR to DAR [128-130]. DuRHAM et al. [129] observed that increasing the intensity of exposure to the causal agent (i.e. TDI, maleic anhydride, and carmine dye) for a given duration of exposure, resulted in an earlier occurrence of the LAR. The demonstration of LAR at doses lower than those that provoke EAR suggests that the development of the LAR is largely independent of a preceding EAR, but depends rather on the cumulative dose of the agent and the level of NSBHR. It has been stated that isolated LARs are associated primarily with LMW agents, reflecting non-IgE-dependent mechanisms. However, isolated LARs have also been documented after SIC with HMW allergens [117, 131, 132], although such reactions seem to be rare. It is likely that the association between isolated LARs and LMW agents results from a methodological bias: during SIC the dose of HMW allergens is progressively increased until an immediate $20 \%$ fall in FEV1 is obtained, while exposure to LMW agents is usually increased on separate days.

Nonspecific bronchial hyperresponsiveness. SICs have demonstrated that LARs induced by HMW allergens $[45,46]$ and LMW occupational agents [47, 48] are associated with an increase in NSBHR that occurs $6-8 \mathrm{~h}$ after exposure, and returns to baseline level within a period of $24 \mathrm{~h}$ to 4 weeks $[47,48]$. This increase in NSBHR may precede the development of the late component of DAR, since it has been recorded $1-3 \mathrm{~h}$ after resolution of the immediate response [49-51]. Recently, significant increases in NSBHRs have been documented within $12 \mathrm{~h}$ after isolated EARs to various occupational agents [52]. There is also evidence that repeated challenges with low doses of allergens that do not induce asthmatic reactions can result in enhancement of NSBHR [133]. We have recently confirmed that an increase in NSBHR may precede the occurrence of an asthmatic reaction to occupational agents [37]. These findings are of potential clinical importance, since they indicate that, even in the absence of significant changes in airway calibre, repeated exposures to sensitizing agents may lead to the perpetuation of the NSBHR and, presumably, of the airway inflammation, that are associated with worsening of asthma symptoms.

Airway inflammation. SIC, in conjunction with peripheral blood sampling, BAL and bronchial biopsy procedures, have greatly improved our knowledge of the inflammatory events associated with asthmatic reactions induced by HMW allergens [134]. Studies using these methods have shown that the mechanisms underlying EARs and LARs are likely to be different. The EAR is related to smooth muscle contraction and mucosal oedema resulting from IgE-mediated release of mast cell mediators. By contrast, LARs result from multiple mechanisms that involve not only bronchoconstriction and mucosal oedema, but also the recruitment and activation of inflammatory cells with release of mediators, reactive species of oxygen, and tissue-damaging basic proteins.

BAL studies have shown that the influx of inflammatory cells (neutrophils and eosinophils) associated with LAR elicited by LMW agents is similar to that found in allergic asthma, with the exception that isocyanateasthma may demonstrate a more prominent neutrophil component [135-138]. Increased concentrations of albumin in BAL obtained during LAR induced by isocyanates and plicatic acid suggest the development of microvascular leakage and oedema formation [135-137]. The release of inflammatory mediators has been documented in BAL (i.e., histamine, and leukotriene $\mathrm{E}_{4}$ and $\mathrm{B}_{4}$ ) and peripheral blood (i.e., neutrophil chemotactic factor, eosinophil cationic protein, tumor necrosis factor- $\alpha$ ) during asthmatic reactions induced by LMW agents [137-143].

Steroids suppress the LAR, as well as the influx of neutrophils and eosinophils and the exudation of albumin. These findings further support the importance of airway inflammation in LAR induced by LMW agents [136, 144].

Pharmacomodulation of asthmatic reactions. SIC is a useful in vivo model to assess the efficacy of anti-asthma drugs in suppressing asthmatic reactions induced by 
HMW common allergens [145-168] and LMW occupational agents (table 3) [144, 169-173]. Results of such studies have direct implications for the treatment of asthma and contribute to the enhancement of our understanding of the pathophysiological mechanisms involved in asthmatic reactions.

Effect on EAR. Allergen-induced EAR is effectively prevented by drugs that have a direct bronchodilator effect and/or inhibit IgE-dependent activation of mast cells. Inhaled short-acting $\beta_{2}$-adrenergic agonists (salbutamol, fenoterol) are highly effective in abrogating the EAR to HMW allergens [145-152], probably through both a smooth muscle relaxant effect and an inhibition of mast-cell mediator release. Sodium cromoglycate and nedocromil have an acute protective effect on EAR induced by HMW agents [146-148, 157-159], while sodium cromoglycate does not affect EAR induced by LMW agents [169]. A single dose of inhaled steroid administered before challenge with HMW agents only minimally affects EAR [148], while prolonged administration of inhaled and oral steroids causes either some inhibition of EAR [144, 153, 156, 171] or no effect [169, 170]. As steroids appear to have no effect on IgE-dependent mediator release from mast cells, the effect of short courses of inhaled steroids on EAR could be related to a reduction in the total number of airway mast cells [174] or to a decrease in the level of baseline NSBHR. Antihistamines affect EAR only minimally [166-168], indicating that mediators other than histamine play an important role in the development of the EAR.

Effect on $L A R$. It has been reported that inhaled $\beta_{2}$-agonists administered before allergen challenge are ineffective in preventing an LAR [146, 148, 149] and associated increase in NSBHR [148], although this may be due to their short duration of action. More recently, long-acting $\beta_{2}$-agonists (i.e., salmeterol) [152] and high doses of short-acting $\beta_{2}$-agonists (salbutamol) [150] have been documented as inhibiting both EAR and LAR and reducing the accompanying rise in NSBHR. The suppressive effect of these drugs extended well beyond the duration of bronchodilatation and functional antagonism of histamine-induced bronchoconstriction, suggesting that $\beta_{2}$-agonists may have a pharmacological effect on allergen-induced inflammatory events in addition to their direct relaxant effect on airway smooth muscle. It has been stated that LARs are characteristically less responsive to inhaled $\beta_{2}$-agonists than EAR [10]. However, recent studies have convincingly demonstrated that inhaled bronchodilators administered during LAR induce significant improvement in $\operatorname{FEV}_{1}[52,151]$. Whether $\beta_{2}$-agonists have a shorter bronchodilating effect during LAR than EAR remains to be investigated.

Pre-test administration of inhaled steroids reduces the magnitude of LAR induced by HMW agents as well as the associated increase in NSBHR [148, 153]. Dosedependent inhibition of LAR induced by LMW agents has also been documented after prolonged treatment with inhaled and oral steroids [144, 169-171]. When administered after EAR, inhaled steroids are effective in reducing the LAR [154, 155], but are only slightly effective in inhibiting the increase in NSBHR [154, 155]. This is consistent with the observation that an increase in NSBHR can develop as soon as 1-3 $\mathrm{h}$ after the early component of DAR.

Pre-challenge administration of a single dose of sodium cromoglycate or nedocromil minimally affects the LAR and associated increase in the NSBHR [146, 148, 157, 159, 162, 163]. The same drugs, given in high doses after the EAR, appear to induce a slight reduction of the LAR $[154,160,162,164]$ and associated increase in the NSBHR [154, 160].

\section{Conclusion}

SIC has been largely used as an in vivo model for investigating the pathophysiological mechanisms of asthmatic reactions in humans. Studies in this field have led to the recognition and characterization of the immediate and late components of asthmatic reactions and contributed significantly to our increased understanding of the inflammatory events associated with these reactions. SIC can also be used fruitfully to assess the effect of antiasthma drugs.

SICs in the laboratory represent an old empirical approach to assessing the causal relationship between

Table 3. - Effect of medications on asthmatic reactions induced by low molecular weight occupational agents

\begin{tabular}{|c|c|c|c|c|c|c|c|}
\hline Medication & $\mathrm{n}$ & Agent & Protocol & EAR & LAR & Increase in NSBHR & [Ref.] \\
\hline \multicolumn{8}{|c|}{ Beclomethasone dipropionate (inhaled) } \\
\hline $1 \mathrm{mg}$ b.i.d. & 6 & TDI & $\mathrm{P} / \mathrm{C} ; 7 \mathrm{~d}+\mathrm{PT}$ & No effect & Inhibition & Inhibition at $8 \mathrm{~h}$ & [169] \\
\hline $1 \mathrm{mg}$ b.i.d. & 7 & TDI & $\mathrm{P} / \mathrm{C} ; 7 \mathrm{~d}+\mathrm{PT}$ & No effect & Inhibition & Inhibition at $8 \mathrm{~h}$ & [170] \\
\hline $0.2 \mathrm{mg}$ b.i.d. & 7 & TDI & $\mathrm{P} / \mathrm{C} ; 7 \mathrm{~d}+\mathrm{PT}$ & No effect & Reduction & No effect at $8 \mathrm{~h}$ & [170] \\
\hline \multicolumn{8}{|c|}{ Dexamethasone isonicotinate (inhaled) } \\
\hline $\begin{array}{l}0.5 \mathrm{mg} \text { b.i.d. } \\
\text { Prednisolone }\end{array}$ & 6 & TDI & $7 \mathrm{~d}+\mathrm{PT}$ & Inhibition & Inhibition & No effect & [171] \\
\hline $3 \times 50 \mathrm{mg}$ & 10 & TDI & $2 d+P T$ & Reduction: $2 / 3$ & Inhibition $9 / 10$ & Inhibition at $8 \mathrm{~h}: 9 / 10$ & [144] \\
\hline Sodium cromoglycate & nha & & & & & & \\
\hline $\begin{array}{l}20 \mathrm{mg} \text { q.i.d. } \\
\text { Slow-release theophy }\end{array}$ & $e^{6}$ & TDI & $\mathrm{P} / \mathrm{C} ; 7 \mathrm{~d}+\mathrm{PT}$ & No effect & No effect & No effect at $8 \mathrm{~h}$ & [169] \\
\hline $\begin{array}{l}\quad 6.5 \mathrm{mg} \cdot \mathrm{kg}^{-1} \text { b.i.d. } \\
\text { Ketotifen }\end{array}$ & 6 & TDI & $\mathrm{P} / \mathrm{C} ; 7 \mathrm{~d}+\mathrm{PT}$ & Reduction & Reduction & No effect at $8 \mathrm{~h}$ & [169] \\
\hline $\begin{array}{l}1 \mathrm{mg} \text { b.i.d. } \\
\text { Atropine }\end{array}$ & 6 & TDI & $\mathrm{P} / \mathrm{C} ; 7 \mathrm{~d}+\mathrm{PT}$ & No effect & No effect & No effect at $8 \mathrm{~h}$ & [172] \\
\hline $0.012 \mathrm{mg} \cdot \mathrm{kg}^{-1} \mathrm{SC}$ & 10 & TDI & PT & No effect & No effect & NT & [173] \\
\hline
\end{tabular}

EAR: early asthmatic reaction; LAR: late asthmatic reaction; NSBHR: nonspecific bronchial hyperresponsiveness; TDI: toluene diisocyanate; P/C: placebo controlled design; PT: pre-test administration of the drug; NT: not tested. 
exposure to occupational agents and the development of airflow limitation and/or NSBHR. These tests remain the most reliable and straightforward method for establishing a diagnosis of OA, provided that a proper methodology is used. SIC should be performed more systematically in the clinical and medicolegal assessment of OA, given the medical and socioeconomic consequences of the condition. There is accumulating evidence that SIC can be performed with minimal risk to the subjects, provided that safety requirements and stringent protocols of exposure are carefully observed. The methodology of SIC should be further improved to obtain a more precise control of exposure to occupational agents. Recently designed closed-circuit exposure devices make it possible to produce steady concentrations of occupational agents. Such devices are likely to further increase the safety and validity of the SIC and will contribute to improve the standardization of these tests. SIC should be made more accessible through the formation of specialized diagnostic centres using adequate challenge techniques.

The use of specific inhalation challenge should be further extended to the fields of epidemiology and prevention of occupational asthma. Specific inhalation challenge can be included in epidemiological surveys and surveillance programmes as the final step towards improving the identification of occupational asthma. Preliminary data suggest that specific inhalation challenge could detect subjects with occupational asthma at an early subclinical stage, although prospective studies are required to determine the outcome of these subjects. Specific inhalation challenge represents a useful procedure to evaluate the effectiveness of preventive procedures in subjects with occupational asthma. This approach could be coupled with quantitative assessment of exposure to determine the threshold dose of an agent that induces asthmatic reactions in sensitized subjects. It remains uncertain whether this threshold dose could be used to establish permissible exposure limits in the workplace.

Acknowledgements. The authors would like to thank A. Cartier and J-P. Delwiche for their sustained collaboration and helpful criticisms, and L. Schubert for reviewing the manuscript.

\section{References}

1. Aas K. The bronchial provocation test. Charles C. Thomas Publisher, Springfield, Illinois 1975.

2. Herxheimer $\mathrm{H}$. The late bronchial reaction in induced asthma. Int Arch Allergy Appl Immunol 1952; 3: 323-328.

3. Dominjon-Monnier F, Carton J, Guibert L, Burtin P, Brille D, Kourilsky R. Épreuves ventilatoires aux extraits de moisissures atmosphériques. Rev Franç Mal Resp 1962; 2: 191-202.

4. Colldahl H. The importance of inhalation test in the etiological diagnosis of allergic diseases of the bronchi and the evaluation of the effects of specific hyposensitization treatment. Acta Allergol 1967; 22: 7-12.

5. Pepys J, Riddell RW, Citron KM, Clayton YM, Short EI. Clinical and immunologic significance of aspergillus fumigatus in the sputum. Am Rev Respir Dis 1959; 80: 167-180.

6. Pepys J. Pulmonary aspergillosis, farmer's lung, and rel- ated diseases. In: Samter M, ed. Immunological Diseases. 2nd Edition. St. Louis, Little, Brown and Cie 1965; pp. 693-713.

7. Hargreave FE, Pepys J, Longbottom JL, Wraith DG. Bird breeder's (fancier's) lung. Lancet 1966; 1: 445-449.

8. Pepys J, Pickering CAC, Hughes EG. Asthma due to inhaled chemical agents-complex salts of platinum. Clin Allergy 1972; 2: 391-396.

9. Pickering CAC, Batten JC, Pepys J. Asthma due to inhaled wood dusts - Western red cedar and iroko. Clin Allergy 1972; 2: 213-218.

10. Pepys J, Hutchcroft BJ. Bronchial provocation tests in etiologic diagnosis and analysis of asthma. Am Rev Respir Dis 1975; 112: 829-859.

11. Chan-Yeung M, Malo JL. Aetiological agents in occupational asthma. Eur Respir J 1994; 7: 346-371.

12. Cartier A, Bernstein IL, Burge PS, et al. Guidelines for bronchoprovocation on the investigation of occupational asthma. J Allergy Clin Immunol 1989; 84: 823-829.

13. Sterk PJ, Fabbri LM, Quanjer PH, et al. Airway responsiveness. Standardized challenge testing with pharmacological, physical and sensitizing stimuli in adults. Official statement of the European Respiratory Society. Eur Respir J 1993; 6, Suppl. 16: 53-83.

14. Chan-Yeung M, Malo JL. Occupational asthma. $N$ Engl J Med 1995; 333: 107-112.

15. Perrin B, Lagier F, L'Archevêque J, et al. Occupational asthma: validity of monitoring of peak expiratory flow rates and non-allergic bronchial responsiveness as compared to specific inhalation challenge. Eur Respir $J$ 1992; 5: 40-48.

16. Tiffeneau R. Hypersensibilité cholinergo-histaminique pulmonaire de l'asthmatique. Relation avec l'hypersensibilité allergénique pulmonaire. Acta allergologica 1958; Suppl V: 187-221.

17. Cockcroft DW, Murdock KY, Kirby J, Hargreave F. Prediction of airway responsiveness to allergen from skin sensitivity to allergen and airway responsiveness to histamine. Am Rev Respir Dis 1987; 135: 264-267.

18. Walsh BJ, Wrigley CW, Musk AW, Baldo BA. A comparison of the binding of $\operatorname{IgE}$ in the sera of patients with bakers' asthma to soluble and insoluble wheat-grain proteins. J Allergy Clin Immunol 1985; 76: 23-28.

19. Cloutier Y, Lagier F, Lemieux R, et al. New methodology for specific inhalation challenges with occupational agents in powder form. Eur Respir J 1989; 2: 769-777.

20. Cloutier Y, Lagier F, Cartier A, Malo JL. Validation of an exposure system to particles for the diagnosis of occupational asthma. Chest 1992; 102: 402-407.

21. Cloutier Y, Malo JL. Update on an exposure system for particles in the diagnosis of occupational asthma. Eur Respir J 1992; 5: 887-890.

22. Vandenplas O. Occupational asthma due to natural rubber latex. Eur Respir J 1995; 8: 1957-1965.

23. Vandenplas 0, Malo JL, Saetta M, Mapp CE, Fabbri LM. Occupational asthma and extrinsic alveolitis due to isocyanates: current status and perspectives. $\mathrm{Br} \mathrm{J}$ Ind Med 1993; 50: 213-228.

24. Banks DE, Tarlo SM, Masri F, Rando RJ, Weissman $\mathrm{DN}$. Bronchoprovocation tests in the diagnosis of isocyanate-induced asthma. Chest 1996; 109: 1370-1379.

25. Vandenplas O, Cartier A, Lesage J, Perrault G, Grammer LC, Malo JL. Occupational asthma caused by a prepolymer but not the monomer of toluene diisocyanate (TDI). J Allergy Clin Immunol 1992; 89: $1183-1188$ 
26. Vandenplas O, Cartier A, Cloutier Y, et al. Prepolymers of hexamethylene diisocyanate (HDI) as a cause of occupational asthma. J Allergy Clin Immunol 1993; 91: 850-861.

27. Lemière C, Desjardins A, Cloutier Y, et al. Occupational asthma due to formaldehyde resin dust with and without reaction to formaldehyde gas. Eur Respir J 1995; 8: 861-865.

28. Vandenplas O, Malo JL, Cartier A, Perreault G, Cloutier Y. Closed-circuit methodology for inhalation challenge test with isocyanates. Am Rev Respir Dis 1992; 145: 582-587.

29. Lemière C, Cloutier Y, Perrault G, Drolet D, Cartier A, Malo JL. Closed-circuit apparatus for specific inhalation challenges with an occupational agent, formaldehyde, in vapor form. Chest 1996; 109: 1631-1635.

30. Vandenplas O, Cloutier Y, Cartier A, Ghezzo H, Malo JL. Response to isocyanates: effect of concentration, duration of exposure and total dose. Am Rev Respir Dis 1993; 147: 1287-1290.

31. Butcher BT, O'Neil CE, Reed MA, Salvaggio JE, Weill $\mathrm{H}$. Development and loss of toluene diisocyanate reactivity: immunologic, pharmacologic, and provocative challenge studies. J Allergy Clin Immunol 1982; 70: 231-235.

32. Cartier A, Malo JL, Forest F, et al. Occupational asthma in snow crab-processing workers. J Allergy Clin Immunol 1984; 74: 261-269.

33. Banks DE, Rando RJ. Recurrent asthma induced by toluene diisocyanate. Thorax 1988; 43: 660-662.

34. Mapp CE, Corona PC, de Marzo N, Fabbri L. Persistent asthma due to isocyanates. A follow-up study of subjects with occupational asthma due to toluene diisocyanate. Am Rev Respir Dis 1988; 137: 1326-1329.

35. Paggiaro PL, Vagaggini B, Dente FL, et al. Bronchial hyperresponsiveness and toluene diisocyanate. Longterm change in sensitized asthmatic subjects. Chest 1993; 103: 1123-1128.

36. Lemière $\mathrm{C}$, Cartier $\mathrm{A}$, Dolovich $\mathrm{J}$, et al. Outcome of specific bronchial responsiveness to occupational agents after removal from exposure. Am J Respir Crit Care Med 1996; 154: 329-333.

37. Vandenplas O, Delwiche JP, Jamart J, Vande Weyer R. Increase in nonspecific bronchial hyperresponsiveness as an early marker of bronchial response to occupational agents during inhalation challenges. Thorax 1996; 51: 472-478.

38. Quanjer PH, Tammeling GJ, Cotes JE, Pedersen OF, Peslin R. Lung volumes and forced ventilatory flows. Official statement of the European Respiratory Society. Eur Respir J 1993; 6: Suppl. 16. 4s-39s.

39. Orehek J, Gayrard P, Grimaud C, Charpin J. Effect of maximal respiratory manoeuvres on bronchial sensitivity of asthmatic patients as compared to normal people. Br Med J 1975; 1: 123-125.

40. Gayrard P, Orehek J, Grimaud CH, Charpin J. Mechanisms of the bronchoconstrictor effects of deep inspiration in asthmatic patients. Thorax 1979; 34: 234-240.

41. Sestier M, Pineau L, Cartier A, Martin RR, Malo JL. Bronchial responsiveness to methacholine and effects of respiratory manoeuvres. J Appl Physiol 1984; 56: 122-128.

42. Bérubé D, Cartier A, L'Archevêque J, Ghezzo H, Malo JL. Comparison of peak expiratory flow rate and FEV1 in assessing bronchomotor tone after challenges with occupational sensitizers. Chest 1991; 99: 831-836.

43. Chan-Yeung M. Maximal expiratory flow and airway resistance during induced bronchoconstriction in patients with asthma due to western Red Cedar (Thuja plicata). Am Rev Respir Dis 1973; 108: 1103-1110.

44. Dehaut P, Rachiele A, Martin RR, Malo JL. Histamine dose-response curves in asthma: reproducibility and sensitivity of different indices to assess response. Thorax 1983; 38: 516-522.

45. Cockcroft DW, Ruffin RE, Dolovich J, Hargreave FE. Allergen-induced increase in non-allergic bronchial reactivity. Clinical Allergy 1977; 7: 503-513.

46. Cartier A, Thomson NC, Frith PA, Roberts R, Hargreave FE. Allergen-induced increase in bronchial responsiveness to histamine: relationship to the late asthmatic response and change in airway caliber. J Allergy Clin Immunol 1982; 70: 170-177.

47. Cockcroft DW, Cotton DJ, Mink JT. Nonspecific bronchial hyperreactivity after exposure to western red cedar. Am Rev Respir Dis 1979; 119: 505-510.

48. Mapp CE, Polato R, Maestrelli P, Hendrick DJ, Fabbri LM. Time course of the increase in airway responsiveness associated with late asthmatic reactions to toluene diisocyanate in sensitized subjects. J Allergy Clin Immunol 1985; 75: 568-572.

49. Durham SR, Graneek BJ, Hawkins R, Newman-Taylor AJ. The temporal relationship between increases in airway responsiveness to histamine and late asthmatic responses induced by occupational agents. J Allergy Clin Immunol 1987; 79: 398-406.

50. Thorpe JE, Steinberg D, Bernstein IL, Murlas CG. Bronchial reactivity increases soon after the immediate response in dual-responding asthmatic subjects. Chest 1987; 91: 21-25.

51. Durham SR, Craddock CF, Cookson WO, Benson MK. Increases in airway responsiveness to histamine precede allergen-induced late asthmatic responses. J Allergy Clin Immunol 1988; 82: 764-770.

52. Malo JL, Ghezzo H, L'Archevêque J, Cartier A. Late asthmatic reactions to occupational sensitizing agents: frequency of changes in nonspecific bronchial responsiveness and of response to inhaled $\beta_{2}$ adrenergic agent. J Allergy Clin Immunol 1990; 85: 834-842.

53. Cartier A, L'Archevêque J, Malo JL. Exposure to a sensitizing occupationai agent can cause a long-lasting increase in bronchial responsiveness to histamine in the absence of significant changes in airway caliber. J Allergy Clin Immunol 1986; 78: 1185-1189.

54. Hendrick DJ, Marshall R, Faux JA, Krall JM. Positive "alveolar" responses to antigen inhalation provocation tests: their validity and recognition. Thorax 1980; 35: 415-427.

55. Vandenplas O, Malo JL, Dugas M, et al. Hypersensitivity pneumonitis-like reaction among workers exposed to diphenylmethane diisocyanate (MDI). Am Rev Respir Dis 1993; 147: 338-346.

56. Lemière $\mathrm{C}$, Gautrin $\mathrm{D}$, Trudeau $\mathrm{C}$, et al. Fever and leucocytosis accopmpanying asthmatic reactions due to occupational agents; frequency and associated factors. Eur Respir J 1996; 9: 517-523.

57. Durham SR, Kay AB. Eosinophils, bronchial hyperreactivity and late-phase asthmatic reactions. Clin Allergy 1985; 15: 411-418.

58. Semenzato G, Bjermer L, Costabel U, Haslam PL, Olivieri $\mathrm{D}$, Trentin L. Clinical role of bronchoalveolar lavage in extrinsic allergic alveolitis. Eur Respir Rev 1992; 8: 69-74.

59. Stenton SC, Avery AJ, Walters EH, Hendrick DJ. Statistical approaches to the identification of late asthmatic reactions. Eur Respir J 1994; 7: 806-812. 
60. Perrin B, Cartier A, Ghezzo H, et al. Reassessment of the temporal patterns of bronchial obstruction after exposure to occupational sensitizing agents. J Allergy Clin Immunol 1991; 87: 630-639.

61. Cartier A, Malo JL, Dolovich J. Occupational asthma in nurses handling psyllium. Clin Allergy 1987; 17: 1-6.

62. Siracusa A, Curradi F, Abbritti G. Recurrent nocturnal asthma due to tolylene di-isocyanate: a case report. Clin Allergy 1978; 8: 195-201.

63. Newman-Taylor AJ, Davies RJ, Hendrick DJ, Pepys J. Recurrent nocturnal asthmatic reactions to bronchial provocation tests. Clin Allergy 1979; 9: 213-219.

64. Cockcroft DW, Hoeppner VH, Werner GD. Recurrent nocturnal asthma after bronchoprovocation with Western Red Cedar sawdust: association with acute increase in non-allergic bronchial responsiveness. Clin Allergy 1984; 14: 61-68.

65. Moller DR, Brooks SM, Bernstein Dl, Cassedy K, Enrione M, Bernstein IL. Delayed anaphylactoid reaction in a worker exposed to chromium. J Allergy Clin Immunol 1986; 77: 451-456.

66. Romano C, Sulotto F, Pavan I, Chiesa A, Scansetti G. A new case of occupational asthma from reactive dyes with severe anaphylactic response to the specific challenge. Am J Ind Med 1992; 21: 209-216.

67. Lagier F, Cartier A, Malo JL. Statistiques médicolégales sur l'asthme professionnel au Québec de 1986 à 1988. Medico-legal statistics on occupational asthma in Quebec between 1986 and 1988. Rev Mal Respir 1990; 7: 337-341

68. Meredith SK, Taylor VM, McDonald JC. Occupational respiratory disease in the United Kingdom 1989: a report to the British Thoracic Society and the Society of Occupational Medicine by the SWORD project group. Br J Ind Med 1991; 48: 292-298.

69. Contreras GR, Rousseau R, Chan-Yeung M. Occupational respiratory diseases in British Columbia, Canada in 1991. Occup Environ Med 1994; 51: 710-712.

70. Meredith S, Nordman H. Occupational asthma: measures of frequency from four countries. Thorax 1996; 51: 435-440.

71. Paggiaro PL, Vagaggini B, Bacci E, et al. Prognosis of occupational asthma. Eur Respir J 1994; 7: 761-767.

72. Hendrick DJ. Management of occupational asthma. Eur Respir J 1994; 7: 961-968.

73. Venables KM, Davison AG, Newman-Taylor AJ. Consequences of occupational asthma. Respir Med 1989; 83: 437-440.

74. Gannon PFG, Weir DC, Robertson AS, Burge PS. Health, employment, and financial outcomes in workers with occupational asthma. Br J Ind Med 1993; 50: 491-496.

75. Marabini A, Ward H, Kwan S, Kennedy S, WexlerMorrison N, Chan-Yeung M. Clinical and socioeconomical features of subjects with red cedar asthma. A follow up study. Chest 1993; 104: 821-824.

76. Dewitte JD, Chan-Yeung M, Malo JL. Medicolegal and compensation aspects of occupational asthma. Eur Respir $J$ 1994; 7: 969-980.

77. Venables KM. Prevention of occupational asthma. Eur Respir J 1994; 7: 768-778.

78. Cartier A. Definition and diagnosis of occupational asthma. Eur Respir J 1994; 7: 153-160.

79. Malo JL, Ghezzo H, L'Archevêque J, Lagier F, Perrin $\mathrm{B}$, Cartier A. Is the clinical history a satisfactory means of diagnosing occupational asthma? Am Rev Respir Dis 1991; 143: 528-532.

80. Cartier A, Grammer L, Malo JL, et al. Specific serum antibodies against isocyanates: association with occu- pational asthma. J Allergy Clin Immunol 1989; 84: 507-514.

81. Burge PS. Non-specific bronchial hyper-reactivity in workers exposed to toluene di-isocyanate, diphenyl methane di-isocyanate and colophony. Eur J Respir Dis 1982; 63, Suppl 123: 91-96.

82. Osterman K, Johansson SGO, Zetterström O. Diagnostic tests in allergy to green coffee. Allergy 1985; 40: 336-343.

83. Bardy JD, Malo JL, Séguin P, et al. Occupational asthma and IgE sensitization in a pharmaceutical company processing psyllium. Am Rev Respir Dis 1987; 135: 1033-1038.

84. Merget R, Stollfuss J, Wiewrodt R, et al. Diagnostic tests in enzyme allergy. J Allergy Clin Immunol 1993; 92: 264-277.

85. Bernstein D1, Smith AB, Moller DR, et al. Clinical and immunologic studies among egg-processing workers with occupational asthma. J Allergy Clin Immunol 1987; 80: 791-797.

86. Smith AB, Bernstein DI, London MA, et al. Evaluation of occupational asthma from airborne egg protein exposure in multiple settings. Chest 1990; 98: 398-404.

87. Cartier A, Malo JL, Ghezzo H, McCants M, Lehrer SB. IgE sensitization in snow crab-processing workers. $J$ Allergy Clin Immunol 1986; 78: 344-348.

88. Venables KM. Low molecular weight chemicals, hypersensitivity, and direct toxicity: the acid anhydrides. $\mathrm{Br}$ $J$ Ind Med 1989; 46: 222-322.

89. Merget R, Schultze-Werninghaus G, Bode F, Bergmann EM, Zachgo W, Meier-Sydow J. Quantitative skin prick and bronchial provocation tests with platinum salts. $\mathrm{Br}$ J Ind Med 1991; 48: 830-837.

90. Shirakawa T, Kusaka Y, Fujimura N, Goto S, Morimoto $\mathrm{K}$. The existence of specific antibodies to cobalt in hard metal asthma. Clin Allergy 1988; 18: 451-460.

91. Park HS, Lee MK, Kim BO, et al. Clinical and immunologic evaluations of reactive dye-exposed workers. $J$ Allergy Clin Immunol 1991; 87: 639-649.

92. Moscato G, Godnic-Cvar J, Maestrelli P, Malo JL, Burge PS, Coifman R. Statement on self-monitoring of peak expiratory flows in the investigation of occupational asthma. Eur Respir J 1995; 8: 1605-1610.

93. Côté J, Kennedy S, Chan-Yeung M. Sensitivity and specificity of $\mathrm{PC}_{20}$ and peak expiratory flow rate in cedar asthma. J Allergy Clin Immunol 1990; 85: 592-598.

94. Beckett WS. The epidemiology of occupational asthma. Eur Respir J 1994; 7: 161-164.

95. Zammit-Tabona M, Sherkin M, Kijek K, Chan H, ChanYeung M. Asthma caused by diphenylmethane diisocyanate in foundry workers. Clinical, bronchial provocation, and immunologic studies. Am Rev Respir Dis 1983; 128 : 226-230.

96. Séguin P, Allard A, Cartier A, Malo JL. Prevalence of occupational asthma in spray painters exposed to several types of isocyanates, including polymethylene polyphenylisocyanates. J Occup Med 1987; 29: 340-344.

97. Bernstein DI, Korbee L, Stauder T, et al. The low prevalence of occupational asthma and antibody-dependent sensitization to diphenylmethane diiosocyanate in a plant engineered for minimal exposure to diisocyanates. J Allergy Clin Immunol 1993; 92: 387-396.

98. Wernfors M, Nielsen J, Schutz A, Skerfving S. Phthalic anhydride-induced occupational asthma. Int Arch Allergy Appl Immunol 1986; 79: 77-82.

99. Blainey AD, Ollier S, Cundell D, Smith RE, Davies RJ. Occupational asthma in a hairdressing salon. Thorax 1986; 41: 42-50. 
100. Park HS, Lee MK, Kim BO, et al. Clinical and immunologic evaluations of reactive dye-exposed workers. $J$ Allergy Clin Immunol 1991; 87: 639-649.

101. Malo JL, Cartier A. Occupational asthma in workers of a pharmaceutical company processing spiramycin. Thorax 1988; 43: 371-377.

102. Malo JL, Cartier A, L'Archevêque J, Trudeau C, Courteau JP, Bhérer L Prevalence of occupational asthma among workers exposed to Eastern White Cedar. Am J Respir Crit Care Med 1994; 150: 1697-1701.

103. Malo JL, Cartier A, L'Archevêque J, et al. Prevalence of occupational asthma and immunological sensitization to guar gum among employees at a carpet-manufacturing plant. J Allergy Clin Immunol 1990; 86: 562-569.

104. Malo JL, Cartier A, L'Archevêque J, et al. Prevalence of occupational asthma and immunologic sensitization to psyllium among health personnel in chronic care hospitals. Am Rev Respir Dis 1990; 142: 1359-1366.

105. Tarlo SM, Wong L, Roos J, Booth N. Occupational asthma caused by latex in a surgical glove manufacturing plant. J Allergy Clin Immunol 1990; 85: 626-631.

106. Vandenplas O, Delwiche JP, Evrard G, et al. Prevalence of occupational asthma due to latex among hospital personnel. Am J Respir Crit Care Med 1995; 151: 54-60.

107. Desjardins A, Malo JL, L'Archevêque J, Cartier A, McCants M, Lehrer SB. Occupational IgE-mediated sensitization and asthmatic reactions to clam and shrimp. J Allergy Clin Immunol 1995; 96: 608-617.

108. Newman-Taylor AJ. Asthma. In: McDonald J, ed. Epidemiology of Work Related Diseases. London, BMJ Publishing Group, 1995; pp. 117-142.

109. Chatham M, Bleecker ER, Norman P, Smith PL, Mason P. A screening test for airways reactivity. An abbreviated methacholine inhalation challenge. Chest 1982; 82: $15-18$

110. Yan K, Salome C, Woolcock AJ. Rapid method for measurement of bronchial responsiveness. Thorax 1983; 38: 760-765.

111. Hendrick DJ, Fabbri LM, Hughes JM, et al. Modification of the methacholine inhalation test and its epidemiologic use in polyurethane workers. Am Rev Respir Dis 1986; 133: 600-604

112. Burge PS. Single and serial measurements of lung function in the diagnosis of occupational asthma. Eur $J$ Respir Dis 1982; 63 (Suppl. 123): 47-59.

113. Venables KM, Burge PS, Davison AG, Newman-Taylor AJ. Peak flow rate records in surveys: reproducibility of observers' reports. Thorax 1984; 39: 828-832.

114. Gordon S, Tee RD, Lowson D, Wallace J, NewmanTaylor AJ. Reduction of airborne allergenic urinary proteins from laboratory rats. Br J Ind Med 1992; 49: 416-422.

115. Tarlo SM, Sussman G, Contala A, Swanson MC. Control of airborne latex by use of powder-free latex gloves. J Allergy Clin Immunol 1994; 93: 985-989.

116. Machado L, Olsson G, Stalenheim S, Zetterström O. Dust exposure challenge test as a measure of potential allergenicity and occupational disease risk in handling of ispaghula products. Allergy 1983; 38: 141-144.

117. Vandenplas O, Delwiche JP, Depelchin S, Sibille Y, Vande Weyer R, Delaunois L. Latex gloves with a lower protein content reduce bronchial reactions in subjects with occupational asthma due to latex. Am J Respir Crit Care Med 1995; 151: 887-891.

118. Slovak AJM, Orr RG, Teasdale EL. Efficacy of the helmet respirator in occupational asthma due to laboratory animal allergy (LAA). Am Ind Hyg Assoc J 1985; 46: 411-415.
119. Kongerud J, Rambjør $\varnothing$. The influence of the helmet respirator on peak flow rate in aluminum potroom. Am Ind Hyg Assoc J 1991; 52: 243-248.

120. Boulet LP, Roberts RS, Dolovich J, Hargreave FE. Prediction of late asthmatic responses to inhaled allergen. Clin Allergy 1984; 14: 379-385.

121. McIntyre D, Boyd G. Factors influencing the occurrence of late reactions to allergen challenge in atopic asthmatics. Clin Allergy 1984; 14: 311-317.

122. Ihre E, Axelsson IGK, Zetterström O. Late asthmatic reactions and bronchial variability after challenge with low doses of allergen. Clin Allergy 1988; 18: 557-567.

123. Lai CKW, Twentyman OP, Holgate ST. The effect of an increase in inhaled allergen dose after rimiterol hydrobromide on the occurrence and magnitude of the late asthmatic response and the associated change in nonspecific bronchial responsiveness. Am Rev Respir Dis 1989; 140: 917-923.

124. Machado L, Stalenheim G. Factors influencing the occurrence of late bronchial reactions after allergen challenge. Allergy 1990; 45: 268-274.

125. Frolund L, Masen B, Scharling B, Heinig JH, GernerSvendsen U. Bronchial allergen challenge: dose versus concentration. Clin Exp Allergy 1992; 22: 219-225.

126. Mohiuddin AA, Martin RJ. Circadian basis of the late asthmatic response. Am Rev Respir Dis 1990; 142: 1153-1157.

127. Paggiaro PL, Innocenti A, Bacci E, Rossi O, Talini D. Specific bronchial reactivity to toluene diisocyanate: relationship with baseline clinical findings. Thorax 1986; 41: 279-282.

128. Lam S, Tan F, Chan G, Chan-Yeung M. Relationship between types of asthmatic reaction, nonspecific bronchial reactivity, and specific IgE antibodies in patients with red cedar asthma. J Allergy Clin Immunol 1983; 72: 134-139.

129. Durham SR, Graneek BJ, Hawkins R, Newman-Taylor AJ. The temporal relationship between increases in airway responsiveness to histamine and late asthmatic responses induced by occupational agents. J Allergy Clin Immunol 1987; 79: 398-406.

130. Stenton SC, Dennis JH, Hendrick DJ. Occupational asthma due to ceftazidime. Eur Respir J 1995; 8: 1421-1423.

131. Machado L, Stalenheim G, Malmberg P. Early and late allergic bronchial reactions: physiological characteristics. Clin Allergy 1986; 16: 111-117.

132. Lemière $\mathrm{C}$, Cartier A, Dolovich J, Malo JL. Isolated late asthmatic reaction after exposure to a high-molecularweight occupational agent, subtilisin. Chest 1996; 110: $823-824$.

133. Ihre E, Zetterström O. Increase in non-specific bronchial responsiveness after repeated inhalation of low doses of allergen. Clin Exp Allergy 1993; 23: 298-305.

134. Smith DL, Deshazo RD. Bronchoalveolar lavage in asthma. Am Rev Respir Dis 1993; 148: 523-532.

135. Fabbri LM, Boschetto P, Zocca E, et al. Bronchoalveolar neutrophilia during late asthmatic reactions induced by toluene diisocyanate. Am Rev Respir Dis 1987; 136: 36-42.

136. Boschetto P, Fabbri LM, Zocca E, et al. Prednisone inhibits late asthmatic reactions and airway inflammation induced by toluene diisocyanate in sensitized subjects. J Allergy Clin Immunol 1987; 80: 261-267.

137. Lam S, LeRiche J, Phillips D, Chan-Yeung M. Cellular and protein changes in bronchial lavage fluid after late asthmatic reaction in patients with red cedar asthma. $J$ Allergy Clin Immunol 1987; 80: 44-50.

138. Chan-Yeung M, Chan H, Salari H, Lam S. Histamine, leukotrienes and prostaglandins release in bronchial 
fluid during plicatic acid-induced bronchoconstriction. J Allergy Clin Immunol 1989; 84: 762-768.

139. Sastre J, Banks DE, Lopez M, Barkman HW, Salvaggio JE. Neutrophil chemotactic activity in toluene diisocyanate (TDI)-induced asthma. J Allergy Clin Immunol 1990; 85: 567-572.

140. Zocca E, Fabbri LM, Boschetto $\mathrm{P}$, et al. Leukotriene $\mathrm{B}_{4}$ and late asthmatic reactions induced by toluene diisocyanate. J Appl Physiol 1990; 68: 1576-1580.

141. Manning PJ, Rokach J, Malo JL, et al. Urinary leukotriene E4 levels during early and late asthmatic responses. $J$ Allergy Clin Immunol 1990; 86: 211-220.

142. Siracusa A, Vecchiarelli A, Brugnani G, Mirabini A, Felicioni D, Severini C. Changes in interleukin-1 and tumor necrosis factor production by peripheral blood monocytes after specific bronchoprovocation test in occupational asthma. Am Rev Respir Dis 1992; 146: 408412.

143. Mapp CE, Plebani M, Faggiani D, et al. Eosinophil cationic protein $(\mathrm{ECP})$, histamine and tryptase in peripheral blood before and during inhalation challenge with toluene diisocyanate (TDI) in sensitized subjects. Clin Exp Allergy 1994; 24: 730-736.

144. Fabbri LM, Chiesura-Corona P, Dal Vecchio L, et al. Prednisone inhibits late asthmatic reactions and the associated increase in airway responsiveness induced by toluene-diisocyanate in sensitized subjects. Am Rev Respir Dis 1985; 132: 1010-1014.

145. Martin GL, Atkins PC, Dunsky EH, Zweiman B. Effects of theophylline, terbutaline, and prednisone on antigeninduced bronchospasm and mediator release. J Allergy Clin Immunol 1980; 66: 204-212.

146. Hegardt B, Pauwels R, Van Der Straeten M. Inhibitory effect of KWD 2131 , terbutaline and DSCG on the immediate and late allergen-induced bronchoconstriction. Allergy 1981; 36: 115-122.

147. Howarth PH, Durham SR, Lee TH, Kay AB, Church MK, Holgate ST. Influence of albuterol, cromolyn sodium and ipratropium bromide on the airway and circulating mediator responses to allergen bronchial provocation in asthma. Am Rev Respir Dis 1985; 132: 986-992.

148. Cockcroft DW, Murdock KY. Comparative effects of inhaled salbutamol, sodium cromoglycate, and beclomethasone dipropionate on allergen-induced early asthmatic responses, late asthmatic responses, and increased bronchial responsiveness to histamine. J Allergy Clin Immunol 1987; 79: 734-740.

149. Taylor IK, O'Shaughnessy KM, Choudry NB, Adachi M, Palmer JBD, Fuller RW. A comparative study in atopic subjects with asthma of the effects of salmeterol and salbutamol on allergen-induced bronchoconstriction, increase in airway reactivity, and increase in urinary leukotriene $\mathrm{E}_{4}$ excretion. J Allergy Clin Immunol 1992; 89: 575-583.

150. Twentyman OP, Finnerly JP, Holgate ST. The inhibitory effect of nebulized albuterol on the early and late asthmatic reactions and increase in airway responsiveness provoked by inhaled allergen in asthma. Am Rev Respir Dis 1991; 144: 782-787.

151. Van Bever HP, Desager KN, Stevens WJ. The effect of inhaled fenoterol, administered during the late asthmatic reaction to house dust mite (Dermatophagoides pteronyssinus). Allergy Clin Immunol 1990; 85: 700-703.

152. Twentyman OP, Finnerty JP, Harris A, Palmer J, Holgate ST. Protection against allergen-induced asthma by salmeterol. Lancet 1990; 336: 1338-1342.

153. Burge PS, Efthimiou J, Turner-Warwick M, Nelmes
PTJ. Double-blind trials of inhaled beclomethasone diproprionate and fluocortin butyl ester in allergen-induced immediate and late asthmatic reactions. Clin Allergy 1982; 12: 523-531.

154. Cockcroft DW, McParland CP, O'Byrne PM, et al. Beclomethasone given after the early asthmatic response inhibits the late response and the increased methacholine responsiveness and cromolyn does not. J Allergy Clin Immunol 1993; 91: 1163-1168.

155. Paggiaro PL, Dente FL, Morelli MC, et al. Postallergen inhaled budesonide reduces late asthmatic response and inhibits the associated increase of airway responsiveness to methacholine in asthmatics. Am J Respir Crit Care Med 1994; 149: 1447-1451.

156. O'Shaughnessy KM, Wellings R, Gillies B, Fuller RW. Differential effects of fluticasone propionate on allergen-evoked bronchoconstriction and increased urinary leukotriene $\mathrm{E}_{4}$ excretion. Am Rev Respir Dis 1993; 147: 1472-1476.

157. Pepys J, Hargreave FE, Chan M, McCarthy DS. Inhibitory effect of disodium cromoglycate (Intal) on allergen inhalation tests. Lancet 1968; 2: 134-137.

158. Phillips MJ, Ollier S, Gould C, Davies RJ. Effect of antihistamines and antiallergic drugs on responses to allergen and histamine provocation tests in asthma. Thorax 1984; 39: 345-351.

159. Mattoli S, Foresi A, Corbo GM, Polidori G, Ciappi G. Protective effect of disodium cromoglycate on allergeninduced bronchoconstriction and increased hyperresponsiveness: a double-blind placebo-controlled study. Ann Allergy 1986; 57: 295-300.

160. Mattoli S, Foresi A, Corbo GM, Valente S, Ciappi G. Effects of two doses of cromolyn on allergen-induced late asthmatic response and increased responsiveness. $J$ Allergy Clin Immunol 1987; 79: 747-754.

161. Youngchaiyud P, Lee TB. Effect of nedocromil sodium on the immediate response to antigen challenge in asthmatic patients. Clin Allergy 1986; 16: 129-134.

162. Crimi E, Brusasco V, Crimi P. Effect of nedocromil sodium on the late asthmatic reaction to bronchial antigen challenge. J Allergy Clin Immunol 1989; 83: 985-990.

163. Aalbers R, Kauffman HF, Groen H, Koëter GH, De Monchy JGR. The effect of nedocromil sodium on the early and late reaction and allergen-induced bronchial hyperresponsiveness. J Allergy Clin Immunol 1991; 87: 993-1001.

164. Pelikan Z, Knottnerus I. Inhibition of the late asthmatic response by nedocromil sodium administered more than two hours after allergen challenge. J Allergy Clin Immunol 1993; 92: 19-28.

165. Pauwels R, van Renterghem D, van der Straeten M, Johannesson N, Persson CGA. The effect of theophylline and enprofylline on allergen-induced bronchoconstriction. J Allergy Clin Immunol 1985; 76: 583-590.

166. Town GI, Holgate ST. Comparison of the effect of loratadine on the airway and skin responses to histamine, methacholine, and allergen in subjects with asthma. J Allergy Clin Immunol 1990; 86: 886-893.

167. Hamid M, Rafferty P, Holgate ST. The inhibitory effect of terfenadine and flurbiprofen on early and late-phase bronchoconstriction following allergen challenge in atopic asthma. Clin Exp Allergy 1990; 20: 261-267.

168. Twentyman OP, Ollier S, Holgate ST. The effect of H1receptor blockade on the development of early- and latephase bronchoconstriction and increased bronchial responsiveness in allergen-induced asthma. J Allergy Clin Immunol 1993; 91: 1169-1178. 
169. Mapp C, Boschetto P, Dal Vecchio L, et al. Protective effect of antiasthma drugs on late asthmatic reactions and increased airway responsiveness induced by toluene diisocyanate in sensitized subjects. Am Rev Respir Dis 1987; 136: 1403-1407.

170. De Marzo N, Fabbri LM, Crescioli S, M Plebani, R Testi, CE Mapp. Dose-dependent inhibitory effect of inhaled beclomethasone on late asthmatic reactions and increased airway responsiveness to methacholine induced by toluene diisocyanate in sensitized subjects. Pulm Pharmacol 1988; 1: 15-20.

171. Tossin L, Chiesura-Corona P, Leproux GB, et al. Dexamethasone isonicotinate inhibits dual and late asthmatic reactions but not the increase of airway respon- siveness induced by toluene diisocyanate in sensitized subjects. Ann Allergy 1989; 63: 292-296.

172. Tossin L, Chiesura-Corona P, Fabbri LM, et al. Ketotifen does not inhibit asthmatic reactions induced by toluene di-isocyanate in sensitized subjects. Clin Allergy 1989; 19: 177-182.

173. Paggiaro P, Bacci E, Talini D, et al. Atropine does not inhibit late asthmatic responses induced by toluene-diisocyanate in sensitized subjects. Am Rev Respir Dis 1987; 136: $1237-1241$.

174. Djukanovic R, Walls AF, Wilson JW, et al. Effect of an inhaled corticosteroid on airway inflammation and symptoms in asthma. Am Rev Respir Dis 1992; 145: 669-674. 